\title{
Micro-Reactor System for Complete Oxidation of Volatile Organic Compounds
}

\author{
Sunday Odiba ${ }^{1,2}$, Maria Olea ${ }^{2, *}$, Takehiko Sasaki ${ }^{3}$, Emmanuel Iro ${ }^{2}$, Simon Hodgson ${ }^{2}$, \\ Adam Adgar $^{2}$ and Paul Russell ${ }^{2}$ \\ 1 Redcar and Cleveland College, Corporation Rd, Redcar TS10 1EZ, UK; sunday.odiba@cleveland.ac.uk \\ 2 School of Science, Engineering and Design, Teesside University, Tees Valley, Middlesbrough TS1 3BX, UK; \\ iro.emmanuel@googlemail.com (E.I.); S.N.Hodgson@tees.ac.uk (S.H.); a.adgar@tees.ac.uk (A.A.); \\ p.russell@tees.ac.uk (P.R.) \\ 3 Graduate School of Frontier Sciences, The University of Tokyo, 5-1-5, Kashiwanoha, Kashiwa, \\ Chiba 277-8561, Japan; takehiko@k.u-tokyo.ac.jp \\ * Correspondence: m.olea@tees.ac.uk
}

Received: 17 July 2020; Accepted: 24 July 2020; Published: 28 July 2020

\begin{abstract}
Based on previous Computational Fluid Dynamics (CFD) design results, an 11 channel microreactor of dimensions $(0.5 \mathrm{~mm} \times 0.5 \mathrm{~mm} \times 100 \mathrm{~mm})($ width $\times$ depth $\times$ length) and optimal manifold geometry was fabricated, coated with a newly-developed Au/SBA-15 catalyst and then integrated in an experimental rig specifically built for this research. Propane (as model volatile organic compound) oxidation experiments were conducted at three different flow velocities, 12.5, 15.4 and $17.5 \mathrm{~m} / \mathrm{min}$, respectively, at six temperatures, 150, 200, 225, 250, 275, and $300{ }^{\circ} \mathrm{C}$, respectively. The catalyst was prepared by one-pot sol-gel synthesis of SBA-15 with MPTMS (3-mercaptopropyl-trimethoxy-silane) before loading with $\mathrm{HAuCl}_{4}$ gold precursor and then characterized by SEM/EDX, TEM and wide angle XRD. A novel catalyst coating technique was developed, using airbrush ( 0.3 nozzle) to spray a catalyst slurry into the microchannels that produced a thin, firm and uniform layer of Au/SBA-15 catalyst coating inside the microreactor. The experimental measurements revealed that propane conversion increased as the flow feed rates decreased and increased with increasing temperatures in the reactor. For the built microreactor and for the flows and temperatures set, the combustion of propane was possible with measurable conversions and reasonable reactor stability, the performance of the catalyst appeared to be central to the satisfactory operation of the reactor.
\end{abstract}

Keywords: microreactor; CFD; VOCs; Au/SBA-15 catalyst; propane; complete oxidation; catalyst coating

\section{Introduction}

\subsection{VOCs and Elimination Methods}

Volatile organic compounds (VOCs) are stable organic compounds such as alkanes, olefins, alcohols, ketones, aldehydes, esters, aromatic and halogenated hydrocarbons with high vapor pressures due to their low boiling points at room temperature which causes them to vaporize easily into atmospheric environment [1,2]. The European Community (EC) Solvents Emission Directive 1999/13/EC [3] defined VOC as any organic compound having at $20^{\circ} \mathrm{C}$, a vapor pressure of $0.01 \mathrm{kPa}$ or more or having a corresponding volatility under the particular condition of use. The increasing levels of VOCs emitted into the atmosphere constitute major toxic air pollutant in cities and indoor spaces, which is fast becoming a major global health and environmental concern [4-7]. Case studies conducted in different countries all agree that the levels of indoor air VOCs are much higher than outdoor air levels, 
a worrisome development as most people spend more than $80 \%$ of their time in homes, offices and vehicles [8-13]. Inhalation of VOCs over time have been linked to acute diseases such as sick building syndrome (SBS), headaches, fatigue, mucous membrane irritation and chronic diseases such as cancer, leukemia, breakdown of liver, kidney, excretory and central nervous systems. VOCs also contribute significantly to pollution of the atmosphere, causing acid precipitations, photochemical smog and global warming [14-19]. High density of vehicular traffic in urban areas have been identified as the major source of outdoor VOCs as the combustion of fossil fuels from engines exit the exhausts into the atmosphere which can also enter buildings in the area to increase the level of indoor VOCs. Other outdoor sources include large scale use of solvents in industrial processes, petroleum refining and storage, natural gas leakages and surface coatings [7,20-24]. Indoor sources of VOCs include cigarette smoking, heating, wet paints and vanishes, cleaning supplies and pesticides, electronic gadgets, printing ink, adhesives, carpet, synthetic rubber, paper products, pressed wood and insulations [25-28]. With more stringent government regulations on VOCs emission coming on stream [29], a more practical, efficient and cost saving solution is required to eliminate VOCs from industrial and indoor gas streams.

To improve indoor air quality, source control, increased ventilation and air cleaning have been suggested. While it is practically difficult to control the VOCs indoor sources and as increased ventilation might bring in more pollutants from outdoors, air cleaning has been proposed as the most reliable method to eliminate indoor VOCs [8,30]. Industries also require improved and cost saving clean-up systems to eliminate VOCs from their gas streams before discharging them to the atmosphere

The various methods used in elimination of VOCs include adsorption, absorption, condensation, biological treatment, thermal and catalytic oxidation or incineration. Thermal and catalytic oxidation are the most effective methods, however, catalytic oxidation has an edge over thermal oxidation due to its higher VOCs removal capability, lower operating temperature which reduces cost and prevents the formation of harmful reaction intermediates associated with high temperature reactions [1,31-38].

\section{Catalytic Oxidation of VOCs}

Noble metal catalysts $(\mathrm{Pt}, \mathrm{Pd}, \mathrm{Ru}, \mathrm{Ag}, \mathrm{Au})$ have exhibited higher catalytic activity at lower temperatures compared to transition metal catalysts $(\mathrm{Mn}, \mathrm{Co}, \mathrm{Cu}, \mathrm{Fe}, \mathrm{Ni})$ for VOCs oxidation to carbon dioxide and water, however, most of the reported catalysts still operate between $200-500{ }^{\circ} \mathrm{C}$ which makes air clean-up technology expensive, especially for removal of low concentration of VOCs [8,39-43]. Some researchers, however, have reported lower oxidation temperatures with photocatalysis of VOCs using $\mathrm{TiO}_{2}$ even for very low concentrations. Unfortunately, these catalysts, just like most catalysts, are unstable in water, especially at low temperatures, as moisture present in the atmosphere easily deactivate them $[44,45]$. The development of catalysts which can oxidize VOCs below $20{ }^{\circ} \mathrm{C}$ and are resistant to deactivation from moisture will be a major breakthrough into efficient and cost-effective air clean-up technology.

Ever since the unprecedented and extraordinarily high catalytic activity of gold nanoparticles (1-5 nm) towards carbon monoxide oxidation at $-76^{\circ} \mathrm{C}$ was reported by Haruta [46], many researchers have tried to use gold on $\mathrm{Fe}_{2} \mathrm{O}_{3}, \mathrm{TiO}_{2}, \mathrm{CeO}_{2}, \mathrm{Co}_{3} \mathrm{O}_{4}$ and $\mathrm{Mn}_{2} \mathrm{O}_{3}$ supports for low temperature oxidation of VOCs, even though VOCs are much harder to oxidize compared to carbon monoxide due to their higher stability [47]. In most cases, the low temperature oxidation of VOCs by supported gold catalysts has been less impressive compared to platinum, palladium and some transition metal-based catalysts. It therefore seems that the extraordinary capability of gold towards lower temperature oxidation have not been fully exploited for VOCs oxidation reactions. To this end, an attempt was made to develop gold nanoparticles less than $2 \mathrm{~nm}$ supported on highly surface area support for the complete oxidation of VOCs. To the best of our knowledge, no such catalyst has been reported for VOCs oxidation. Gold nanoparticles and SBA-15 mesoporous silica support materials have been reported to be stable in moisture and since SBA-15 offers other exciting features in addition to its high surface area, such as large pore size, large pore volume and thick pore walls for higher hydrothermal stability, a novel Au/SBA-15 catalyst for the elimination of VOCs by complete oxidation at low temperatures 
was successfully developed by our group. Surprisingly, there has been no publication dealing with the VOCs complete oxidation on any Au/SBA-15 catalysts. To boost the commercial viability of the $\mathrm{Au} / \mathrm{SBA}-15$ newly-developed catalyst for VOCs oxidation, this paper proposes an innovative reaction system, namely a large surface area multi-channel microreactor, which only requires very small amounts of catalyst for coating its inner channel's walls. Propane was used as model VOC compound to evaluate the performance of the catalyst coated microreactor.

\subsection{Microreactors}

Microreactors are devices in which chemical reaction takes place in narrow confinement typically less than $100 \mu \mathrm{m}$. Unlike the large traditional reactors, microreactors house chemical reactions to the scale of 5-100 mL. Microreactor are constructed from a network of miniaturized reaction channels. The main distinctions between microreactors and traditional chemical reactors are directly related to their size and especially to their surface-to-volume ratio.

For an ordinary $30 \mathrm{~m}^{3}$ reaction vessel and a microreactor having reaction channels with a diameter of $30 \mu \mathrm{m}$, this ratio is different by a factor of 100,000 . This allows for even very fast and very exothermic reactions to be performed isothermally [48-50] and, in the case of multiphase reactions, the mass transfer path is minimal.

The application of the microreactor technology to catalytic oxidation reactions is proving to be advantageous due to the ability to avoid problems such as high exothermicity and poor control of reaction conditions, commonly associated with catalytic oxidation reactions [51]. Likewise, a microreactor would be an ideal reaction vessel for certain hazardous materials which cannot be dealt with in large-scale processes but can be safely handled in very small quantities. This inherent safety is due to both the small reactant volume being present at any time in the reactor and the well controllable operating reactor and reaction conditions. For instance, diazomethane is extremely toxic and explosive in nature, but owing to the precise control of heat and low residence time in microreactors, diazomethane can be continuously converted to the target product in a safe manner [52]. Some intermediates pose high explosive risk if formed in large quantity in a traditional macroscale system but chemistries with highly energetic intermediates have been successfully studied in microreactors [53]. Fast mixing and diffusion can be achieved in microreactors due to small characteristic size and low volume.

Moreover, the avoidance of mass-transfer limitation is the one of the main objectives in the development of microreactors. For reactions that are mass transfer limited in traditional macroscale systems, the improved mass transfer in microreactor can lead to higher observed reaction rates and process intensification. As for example, the hydrogenation of cyclohexane reaction in a microreactor showed higher mass transfer coefficient of approximately $5-15 \mathrm{~s}^{-1}$ compared to that of conventional reactors of $0.01-0.08 \mathrm{~s}^{-1}$ [54]. Microreactors have been used for production where small quantities of products are required, such as in the pharmaceutical and fine chemical industries and when safety is of a concern. One of the first commercially available microreactors, produced by a collaboration of Caliper Technologies and HP, were designed to be used for medical tests. Microreactors have been used in several research projects including portable energy, assays of proteins and biological analysis of cells and for kinetic and mechanistic studies [55-59]. A number of chemical systems have been successfully integrated with microreactors including ultraviolet and visible spectroscopy and Raman spectroscopy $[60,61]$.

The aim of this work is to use the design, modelling and simulation results, as detailed in our previous study [62], to fabricate, coat and test a microreactor system for propane complete oxidation. The design was performed by using the CFD package of COMSOL Multiphysics to model the flow dynamics and to determine the size and number of channels. The simulations were used to optimize the manifold geometry of the reactor and to find the best operation parameters of the flow system. The designed microreactor with the optimum size and shape is fabricated using a micro-milling machine. A newly-developed Au/SBA-15 catalyst is prepared and physically characterized. The coating of 
the channel's inner walls is achieved by injecting and by spraying of catalyst slurries with different composition. To assess the performance of the catalytic microreactor for propane complete oxidation, a testing ring is built. Experiments with mixtures of propane and air, with ratios around 1:5.5, are performed at temperatures of $150,200,225,250,275$ and $300{ }^{\circ} \mathrm{C}$, respectively, for three different flow rates (three different residence times).

\section{Results and Discussion}

\subsection{Newly-Developed Au/SBA-15 Catalyst Physical Characterization}

The physical characterization results are shown in Table 1 and Figures 1 and 2.

Table 1. Physical properties of the newly-developed Au/SBA-15 catalyst. The BET surface area, pore size and pore volume measured for the support are given for comparison.

\begin{tabular}{cccccc}
\hline Catalyst. & BET Surface Area $\left(\mathbf{m}^{2} / \mathbf{g}\right)$ & Pore Size $(\mathbf{n m})$ & Pore Volume $\left(\mathbf{c m}^{3} / \mathbf{g}\right)$ & Au Loading $(\% w t)$. & Au Size $(\mathbf{n m})$ \\
\hline Au/SBA-15 & 726 & 5.3 & 0.76 & 3.5 & 1.4 \\
\hline SBA-15 & 794 & 5.4 & 0.86 & - & - \\
\hline
\end{tabular}

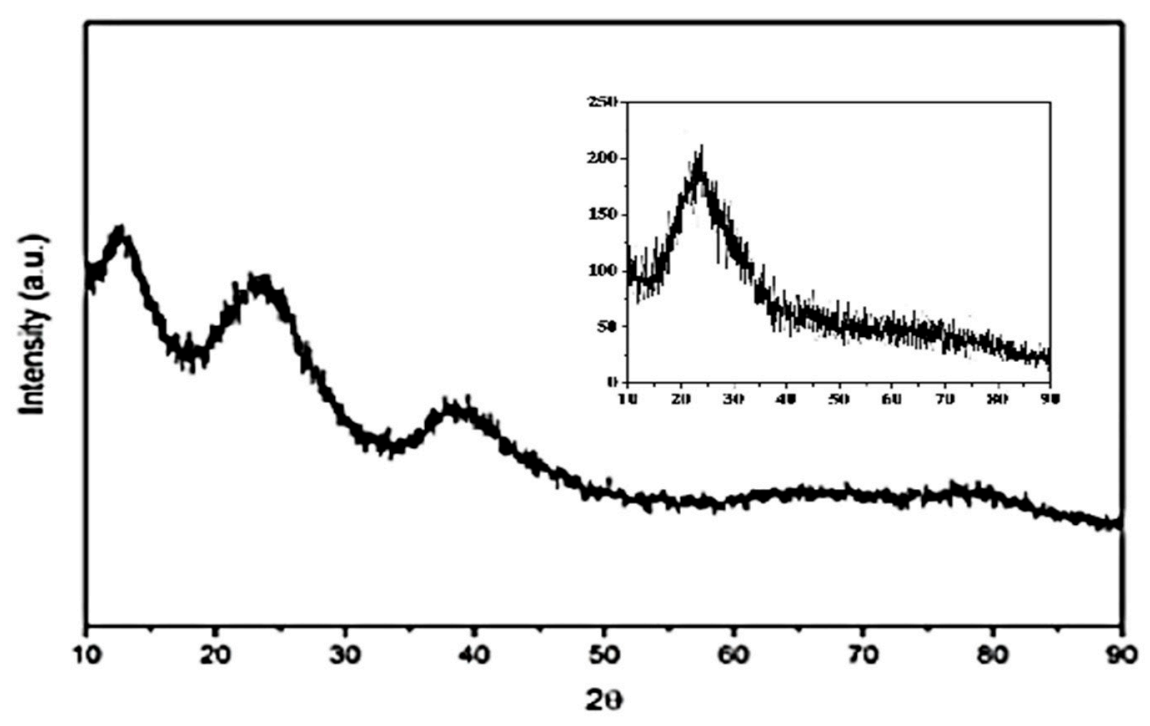

Figure 1. Wide angle XRD of the newly-developed Au/SBA-15 catalyst and SBA-15 (Insert).

Figure 1 shows the wide angle diffractogram of the catalyst along with the support one. As the diffraction peak at $2 \theta=38$ assigned to cubic shaped gold is small and broad, one can conclude that the gold nanoparticles are only small, and, as seen in Figure 2A, they are uniform and well dispersed in the SBA-15 channels. Their size was determined from the TEM images (Figure 2B,C), as equal to $1.4 \mathrm{~nm}$. It can be easily noticed that gold metallic nanoparticles are incorporated and dispersed on the internal surface of the SBA-15, which explains the decrease in BET surface and pore volume and the slight decrease in pore size, as seen in Table 1.

As seen in Figure 2D, the catalyst preserves the worm-like morphology of the support (Figure 2F), which was not altered by the catalyst preparation method used. The primary particle sizes of the catalysts $(1.2-3.1 \mu \mathrm{m}$ lengths and $0.4-0.6 \mu \mathrm{m}$ widths) remained the same with that of the SBA- 15 support. 

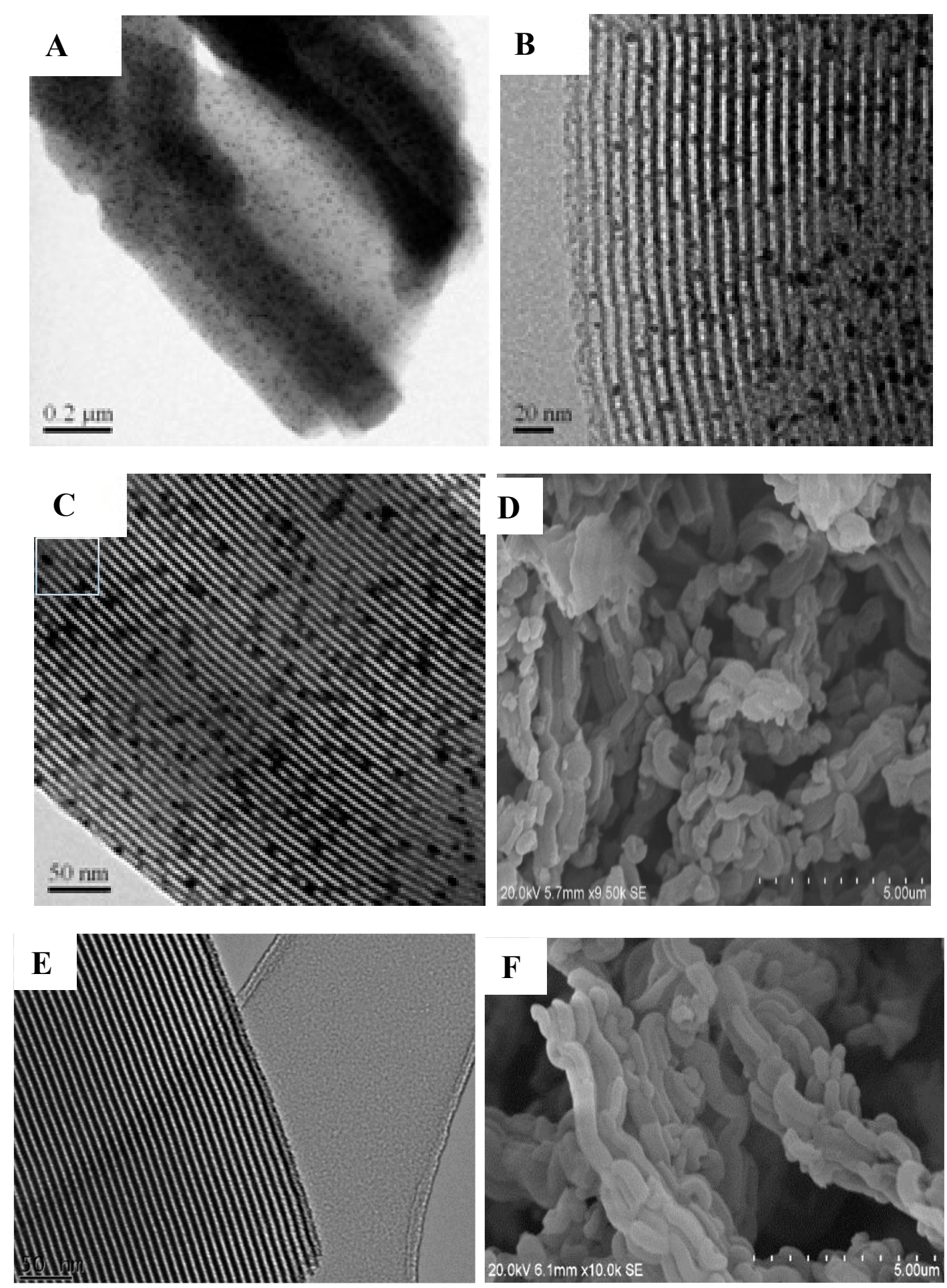

Figure 2. TEM images (A-C) and SEM image (D) of the newly-developed Au/SBA-15 catalyst, TEM and SEM images of SBA-15 (E and F, respectively).

\subsection{Catalyst Coating}

The catalyst-coated microchannels using the three coating techniques described within Section 3.6 were characterized using a GXCAM-5 microscope and a Scanning Electron Microscope Hitachi S-3400 $\mathrm{N}$ variable.

Results obtained by using Technique 1 are presented in Figure 3. 

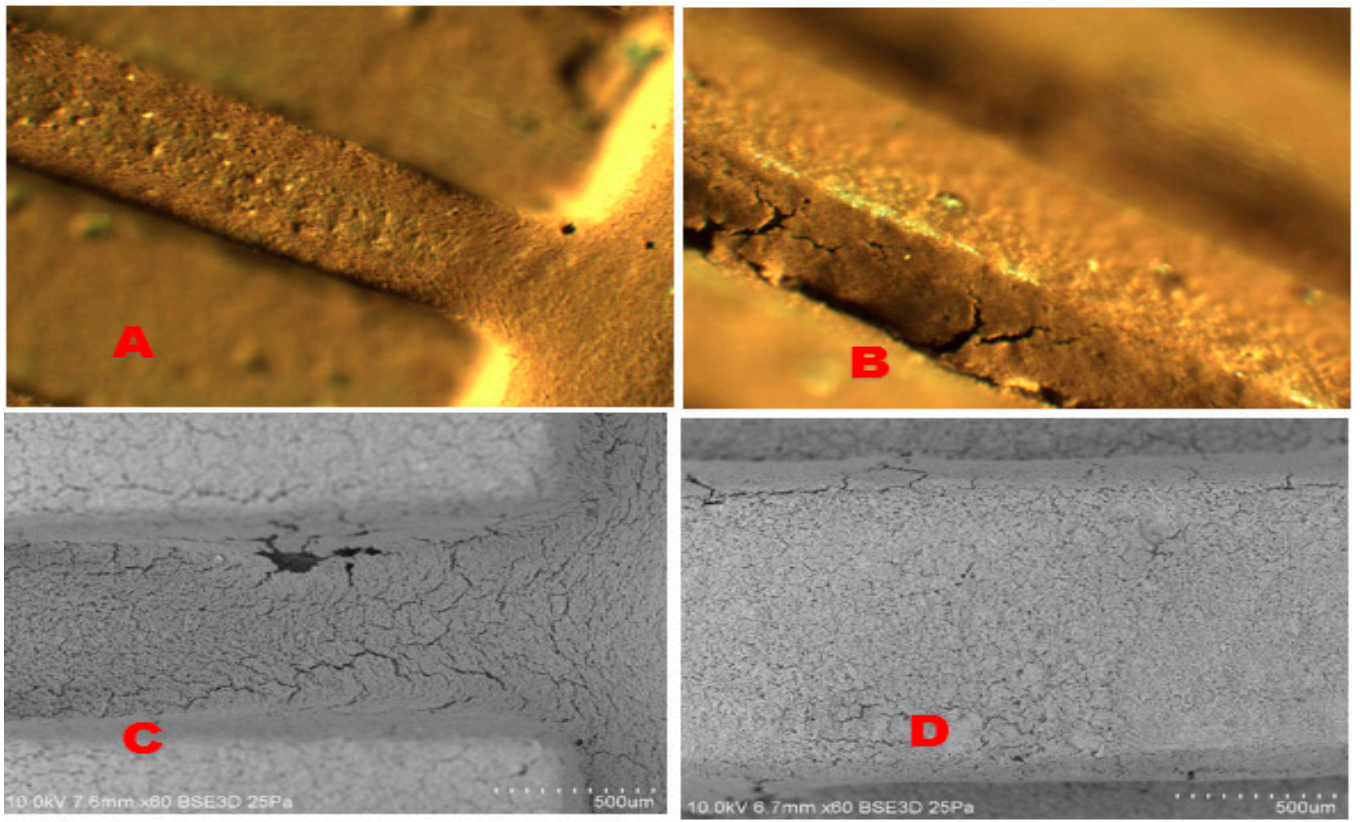

Figure 3. GXCAM-5 microscope images (A,B) and SEM images (C,D) of Au/SBA-15 catalyst coating in the channels of the microreactor before $(\mathbf{A}, \mathbf{C})$ and after $(\mathbf{B}, \mathbf{D})$ heat treatment; Technique 1.

This coating technique failed to produce a thin, firm and uniform catalyst coating. Coating cracks are seen everywhere in the channels which can easily flake off and block the channels of the microreactor. A possible cause could be the burning off the organic binder, which is 60 weight $\%$ more than the catalyst; an enormous amount of stress can be exerted on the coatings, which could lead to cracks even though the heat treatment was slowly ramped by $1 \%$ min.

Results obtained by using the coating Technique 2 are presented in Figure 4.

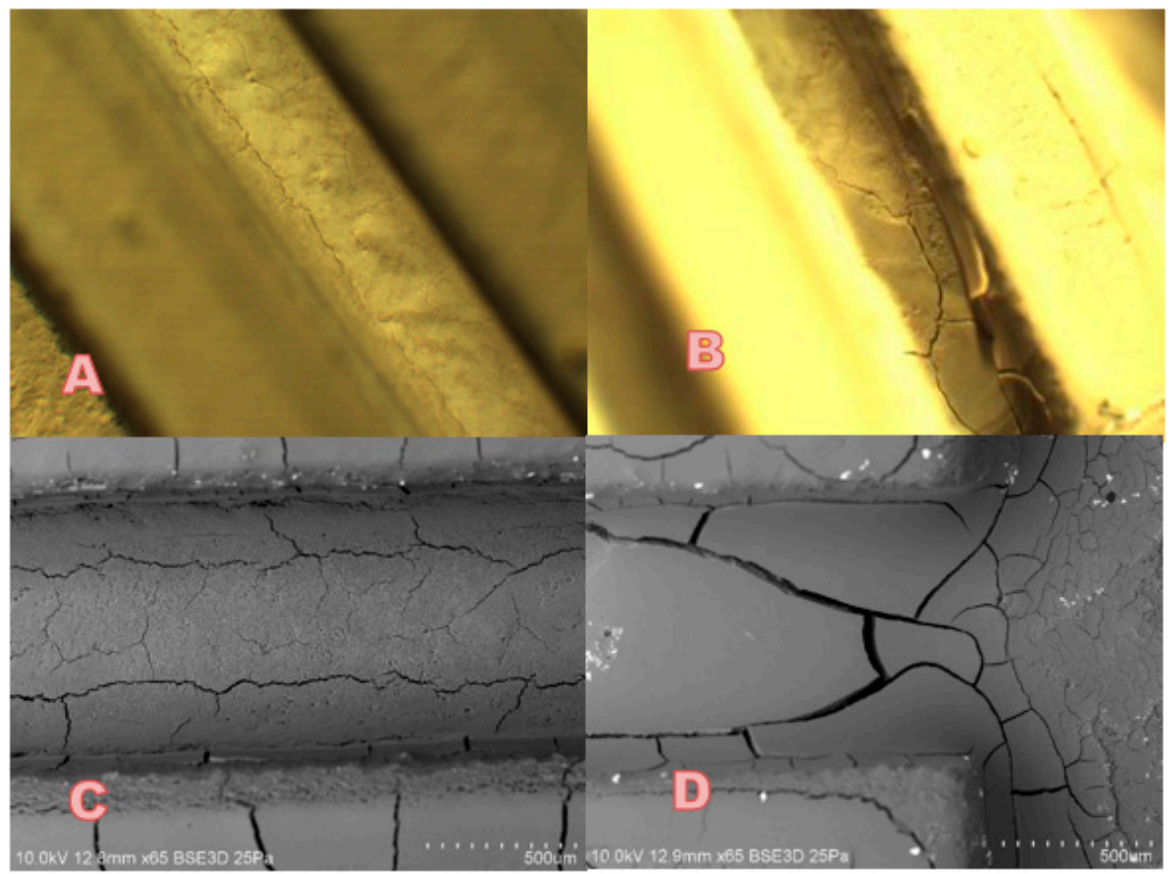

Figure 4. GXCAM-5 microscope images (A,B) and SEM images (C,D) of Au/SBA-15 catalyst coating in the channels of a microreactor before (left) and after (right) heat treatment; Technique 2. 
Unfortunately, this technique produces even deeper cracks all over the channels of the microreactor after air drying.

As for the results obtained by using the coating Technique 3, they are presented in Figure 5.

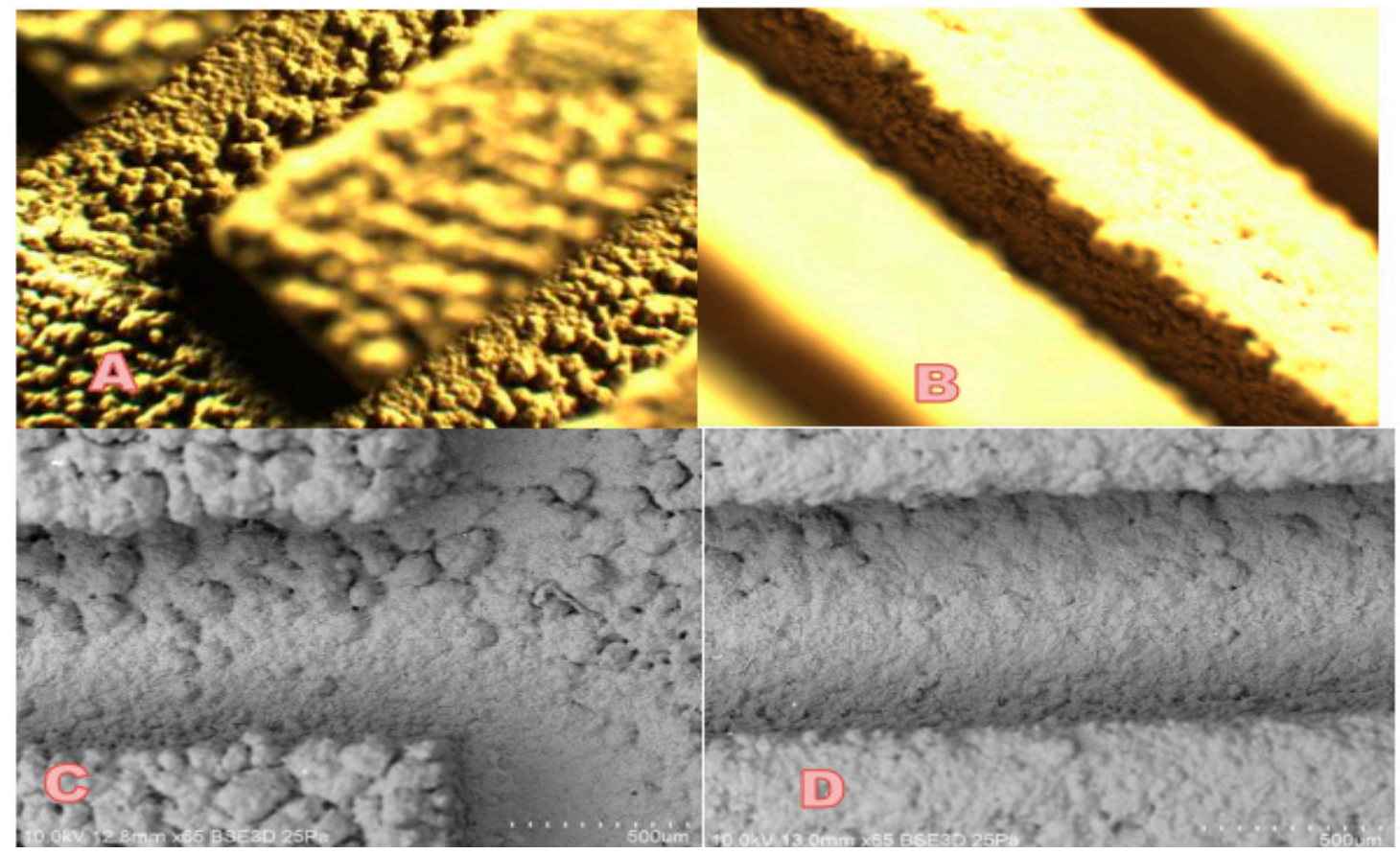

Figure 5. GXCAM-5 microscope images (A,B) and SEM images (C,D) of Au/SBA-15 catalyst coating in the channels of the microreactor before $(\mathbf{A}, \mathbf{B})$ and after $(\mathbf{C}, \mathbf{D})$ heat treatment; Technique 3.

By using this technique, a thin, firm and uniform coating was achieved. No cracks were observed before or after heat treatment with the catalyst coating strongly and uniformly attached to the microchannels.

It is important to note that the coated microreactor is intended for gas phase reactions operated with laminar flow. Liquid phase reactants might wash off the coating and as such, different coating techniques might be required. Unlike the dip coating and syringe method, spraying was done in multiple steps in order to achieve the desired loading or thickness.

\subsection{Catalytic Oxidation of Propane}

Within the limits set by the equipment, three input flow rates, i.e., $27.0,33.2$ and $37.9 \mathrm{~mL} / \mathrm{min}$, respectively, were set and for each flow rate a temperature range from 150 to $300{ }^{\circ} \mathrm{C}$ was investigated. For all three input flow rates, the propane: oxygen molar ratio was kept around 1:5.5 (a slight excess compared to the stoichiometric ratio, as seen in Table 2).

Table 2. Selected propane and air flowrates with molar ratios in the micro-reactor.

\begin{tabular}{ccccccc}
\hline & \multicolumn{2}{c}{ Reactants } & & Fuel: Oxygen Molar Ratio & $\begin{array}{c}\text { Initial Propane Concentration } \\
\text { in the Mixture }\end{array}$ \\
\hline $\begin{array}{c}\text { Propane Flowrate } \\
(\mathrm{mL} / \mathrm{min})\end{array}$ & $\begin{array}{c}\text { Air Flowrate } \\
(\mathrm{mL} / \mathrm{min})\end{array}$ & $\begin{array}{c}\text { Mole\% oxygen in } \\
\text { air flowrate }\end{array}$ & $\begin{array}{c}\text { Total flow } \\
\text { rate }(\mathrm{ml} / \mathrm{min})\end{array}$ & Propane & Oxygen & $(\mathrm{ppm})$ \\
\hline 1.0 & 26.0 & 5.5 & 27.0 & 1.0 & 5.5 & 37,000 \\
\hline 1.2 & 32.0 & 6.7 & 33.2 & 1.0 & 5.6 & 36,000 \\
\hline 1.4 & 36.5 & 7.7 & 37.9 & 1.0 & 5.5 & 37,000 \\
\hline
\end{tabular}

The investigations were carried out in the reactor with the catalyst present and, for comparison, without the catalyst present. The results over the catalyst are presented in Figure 6. 

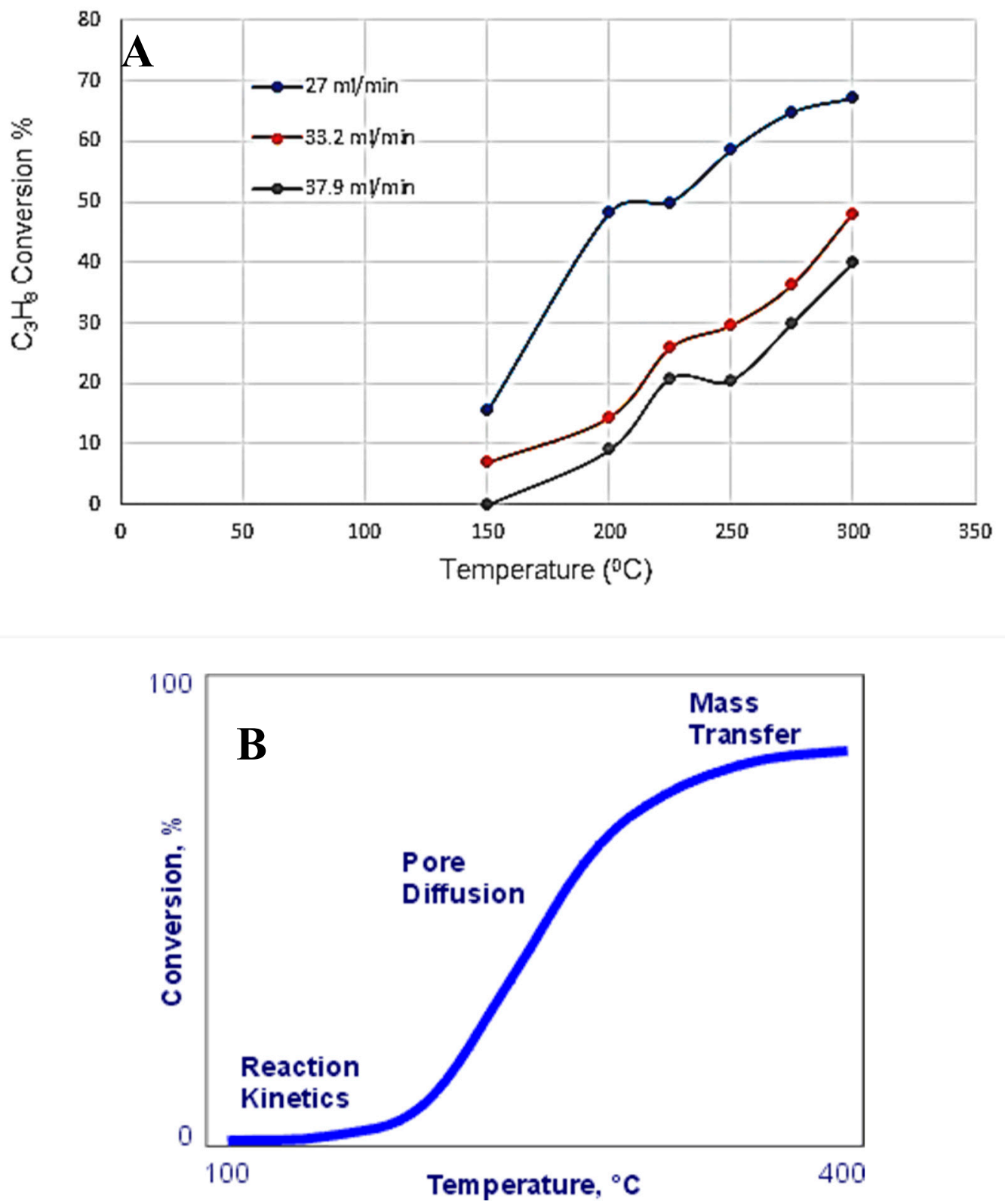

Figure 6. Variation of propane conversion against reaction temperature at different flow rates in the catalytic microreactor (A). Variation of propane conversion against reaction temperature over the same catalyst but in a conventional flow reactor $(\mathbf{B})$.

The complete propane oxidation reaction over the newly-developed Au/SBA-15 catalysts was studied according to Equation (1).

$$
\mathrm{C}_{3} \mathrm{H}_{8}+5 \mathrm{O}_{2}=>3 \mathrm{CO}_{2}+4 \mathrm{H}_{2} \mathrm{O}
$$

Propane conversion was calculated using Equation (2).

$$
X_{\mathrm{C} 3 \mathrm{H} 8}=\frac{\gamma_{i_{\mathrm{C} 3 H 8}}-\gamma_{f_{\mathrm{C} 3 H 8}}}{\gamma_{i_{\mathrm{C} 3 H 8}}} \times 100
$$


where $X_{\mathrm{C} 3 \mathrm{H} 8}$ is the fractional conversion of propane, $\gamma_{i_{\mathrm{C} 3 \mathrm{H}}}$ is the initial partial pressure of propane in torr (taken from the experimental run without catalyst), and $\gamma_{f_{\mathrm{C} 3 H 8}}$ is the final partial pressure of propane (taken from the experimental run with catalyst), in torr.

The propane conversion is presented as a function of temperature for each flow rate. If each flow rate is considered individually, at a flow rate of $27.0 \mathrm{~mL} / \mathrm{min}$ the propane conversion rises from about $15 \%$ to just under $70 \%$ over the temperature range $150-300{ }^{\circ} \mathrm{C}$.

At a flow rate of $33.2 \mathrm{~mL} / \mathrm{min}$, the propane conversion increases with temperature, as expected. However, as a lower residence time is expected (if a proportional calculation is carried out based on the input flow rate, the number of channels in the reactor and the tubular cross sectional area then the unmodified velocities corresponding to $27.0 \mathrm{~mL} / \mathrm{min}$ and $33.2 \mathrm{~mL} / \mathrm{min}$ are $12.5 \mathrm{~m} / \mathrm{min}$ and $15.4 \mathrm{~m} / \mathrm{min}$, respectively), the conversion at each temperature is lower than the one measured at the lower flow rate. The measured difference increases with temperature.

At a higher flow rate, namely $37.9 \mathrm{~mL} / \mathrm{min}$, (where the nominal velocity calculated as above is $17.5 \mathrm{~m} / \mathrm{min}$ ) the same trend of conversion increasing with temperature is observed but as with the previous flow rate, the conversions are lower at the same comparable temperatures. For this flow rate the conversion at $150{ }^{\circ} \mathrm{C}$ is zero.

As expected, the mass transfer limitations at high temperatures are not as severe as those observed in the conventional reactor; in fact, for the flow rates of $33.2 \mathrm{~mL} / \mathrm{min}$ and $37.9 \mathrm{~mL} / \mathrm{min}$, respectively, no mass transfer limitations were observed in the microreactor. At low temperatures, the rate determining step was the reaction kinetics while at intermediate temperatures, the pore diffusion was the main factor affecting the progress of the reaction, for both, microreactor and conventional flow reactor.

From our previous theoretical analyses [62], it was reported that as the temperature in the reactor increased the dominant influence would be the kinetic rate for the oxidation reaction. The simulation results for the oxidation of propane on $\mathrm{Au} / \mathrm{Cr} / \gamma-\mathrm{Al}_{2} \mathrm{O} 3$ catalyst also show a similar trend of conversion of propane increasing with temperature and residence time.

As the kinetic data were not available on the newly-developed Au/SBA-15 catalyst used to coat the microreactor, it was impossible to perform CFD simulations, for a direct comparison with the experimental data on catalytic activity. However, in our previous paper [62], CFD simulation were performed on $\mathrm{Au} / \mathrm{Cr} / \gamma-\mathrm{Al}_{2} \mathrm{O}_{3}$ catalyst, using propane as VOC model compound, at velocities between 0.01 and $1 \mathrm{~m} / \mathrm{s}$ and temperatures between $563\left(290^{\circ} \mathrm{C}\right)$ and $673 \mathrm{~K}\left(390^{\circ} \mathrm{C}\right)$, over all the four microreactor's geometries. The best results were obtained on the A2 geometry. Figure 7 below (taken from our previous paper) shows the propane conversion as a function of temperature, for four flow velocities, $0.01,0.05,0.1$ and $1 \mathrm{~m} / \mathrm{s}$, respectively. 


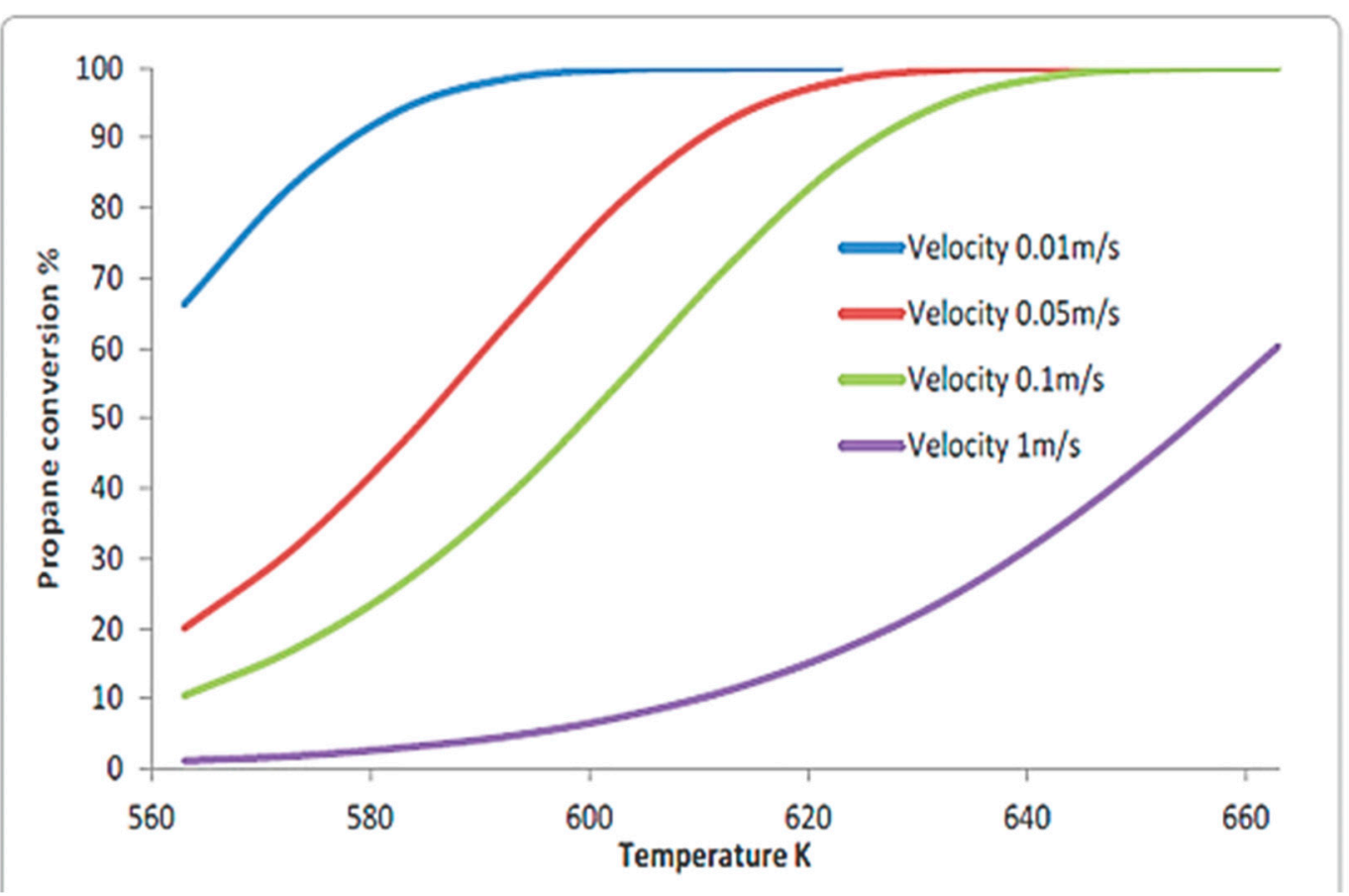

Figure 7. Propane exit conversion against temperature at inlet velocity of $0.01,0.05,0.1$, and $1 \mathrm{~m} / \mathrm{s}$, respectively over $\mathrm{Au} / \mathrm{Cr} / \gamma-\mathrm{Al}_{2} \mathrm{O}_{3}$ catalyst. Reprinted with permission from [62], 2016, Longdom Publishing SL.

The same variation trend, as the one on the Au/SBA-15 catalyst used in this study, is observed for velocities between 0.1 and $1 \mathrm{~m} / \mathrm{s}$ (the velocities used for this study were $0.2,0.26$ and $0.3 \mathrm{~m} / \mathrm{s}$, respectively). This is an indirect confirmation of the same mechanism for total oxidation of propane over both catalysts.

The difference consists on the activity. For the Au/SBA-15 catalyst, as shown in Figure 6, the propane conversion was higher than that obtained on the $\mathrm{Au} / \mathrm{Cr} / \gamma-\mathrm{Al}_{2} \mathrm{O}_{3}$ catalyst, at comparable temperature.

It is interesting to note that for the experiments attempted on the microreactor without the catalyst present there is essentially no significant reaction. This would indicate that for a reactor of this type with the temperatures and flow rates used, the presence of the catalyst is essential for the successful conversion of the VOC.

This planned amount of experimental work gives preliminary indications that a microreactor having the size and geometry described has the potential to deal with small amounts of a typical VOC and produce sensible and predictable results.

\section{Materials and Methods}

\subsection{Brief Presentation of the Design and CFD Modelling and Simulation Results Obtained in Our Previous Study}

A two-stage modelling process was adopted. The first stage dealt with the microchannel modelling based on a simplified model, the dispersion model, while the second stage dealt with CFD simulations for the multichannel microreactor. The residence time distribution (RTD) among parallel microchannels is one of the key design specifications for microreactors, because poor flow uniformity reduces the yield or the selectivity of reaction products.

Stage One: Microchannel's shape and size selection

Although different cross-sections such as rectangular, circular, trapezoidal, triangular, and elliptical have been investigated by several researchers to understand the flow behaviour in microchannels [63-69], the rectangular cross-section was chosen for this study, mainly due to practical 
considerations such as fabrication techniques, cost, ease of manufacturing, as the final goal was to build the microreactor with an optimal configuration and to assess its performance against the modelled one.

For the first stage, a narrow RTD for microchannels was assumed because of the small channel dimensions compared to typical channel length and short lateral diffusion times. The size of the microchannel was then calculated to produce this narrow RTD. The next step was the estimation of the number of parallel microchannels, with the same cross-sectional area and length, to assure equal flow rates in all of them (numbering-up process).

Since the microreactor with the optimum geometry and configuration is foreseen to be used as a mobile devise for indoor VOCs catalytic combustion, a microchannel length of $0.1 \mathrm{~m}$ was chosen. For this length, and for Bodenstein numbers, Bo, higher than 100, the air flow velocity should be lower or equal to $10 \mathrm{~m} / \mathrm{s}$. Under these conditions, the microchannel can be considered as a plug flow reactor. Finally, the proposed microreactor consists of eleven parallel channels of square cross-section, with $0.5 \times 10^{-3} \mathrm{~m}$ width, $0.5 \times 10^{-3} \mathrm{~m}$ height and $0.1 \mathrm{~m}$ length.

Stage Two: CFD simulation of the microreactor

This stage involved the CFD modelling of the microreactor with different configurations (geometries), for cold flow, namely air in this case. The proposed geometries were simulated, and the results were compared to determine the best configuration/geometry for the construction of the catalytic microreactor.

In addition to the effect of the number of branched microchannels and the microchannel's shape and size, the flow distribution is strongly affected by the shape and volume of the inlet and outlet manifolds. The main design challenge was to establish the manifold geometry which allows a uniform flow-distribution into the microchannels. For this reasons, four different geometries namely type A1, A2, A3, and A4 (named according to the shape of the manifold) were proposed as shown Figure 8.

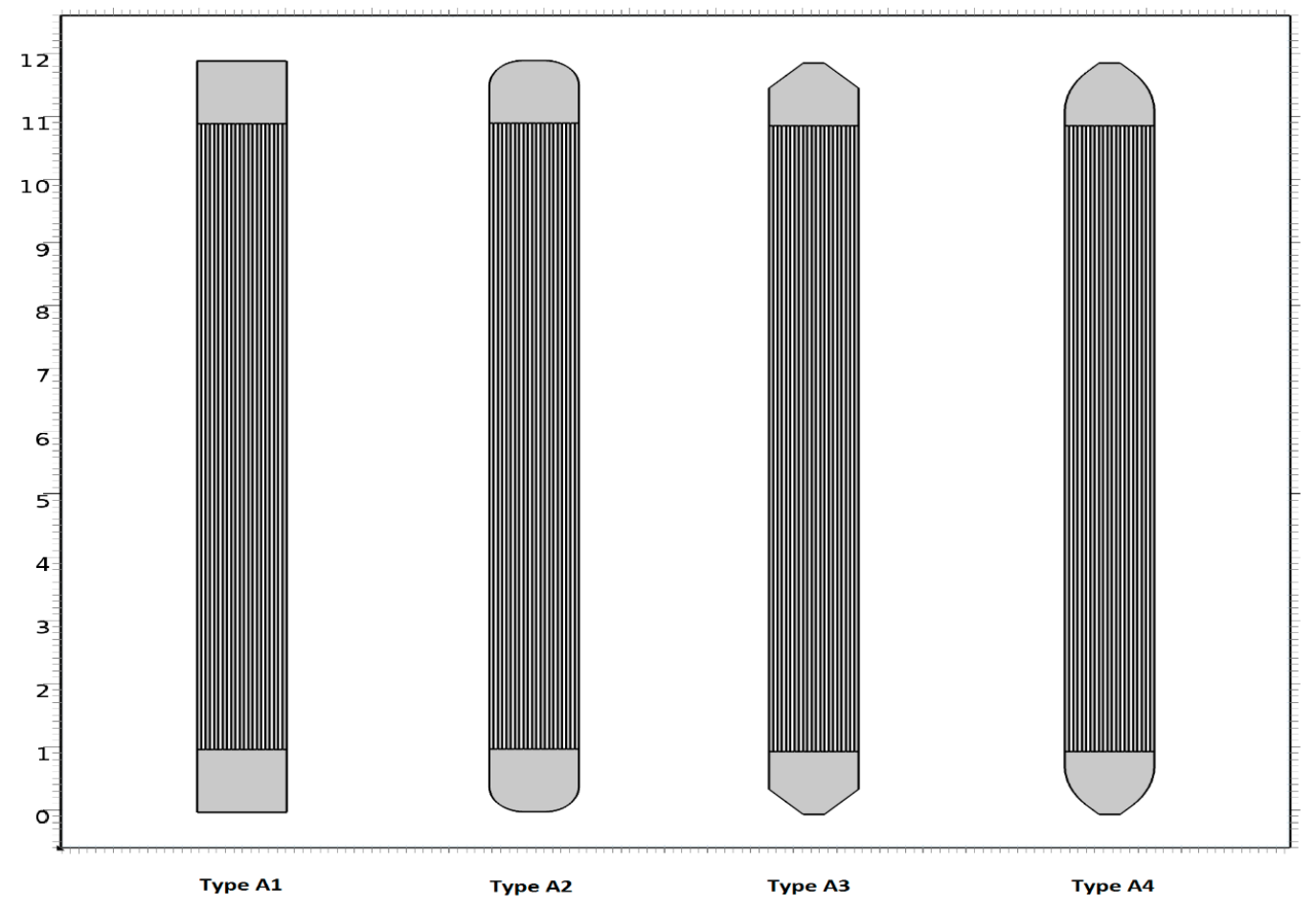

Figure 8. The four proposed microreactors geometries as developed in COMSOL v4.4: Type A1, Type A2, Type A3 and Type A4, respectively [62].

To obtain a quantitative indication of the cold flow behavior in the multiple parallel microchannels, a 2-D model was developed, and numerical simulations were performed for the four proposed geometries, using COMSOL Multiphysics software, in order to determine optimum geometry with 
uniform flow distribution. COMSOL Multiphysics is a powerful interactive environment for modeling and solving of all kinds of scientific and engineering problems based on partial differential equations (PDEs). When solving the PDEs, COMSOL Multiphysics 4.4 uses the finite element method (FEM). In the finite element model, the geometry is divided into several triangles and the differential equations are solved for each node of the resulting mesh. The division of the geometry is called meshing and should obey certain restrictions to guarantee the convergence of the calculations. The software runs the finite element analysis together with adaptive meshing and error control using a variety of numerical solvers.

In our study. the model adopted constant room temperature (since the model was developed for removal of VOCs at room temperature). For this reason and due to the low pressure drop, a constant value of air density was assumed. The Navier-Stokes equations for incompressible flows along with the continuity equation were used to model the air flow [70]. The boundary conditions assumed were:

- no-slip at the walls (which means that the fluid at the wall is not moving),

- fully developed laminar flow,

- uniform velocities for the inflow,

- zero relative pressure for the outflow.

This last boundary condition is physically equivalent to a boundary that is adjacent to a large container (inlet manifold) or exiting into a large container (outlet manifold).

The model equations are the Navier-Stokes equations (conservation of momentum):

$$
\rho \frac{\partial u}{\partial t}+\rho u \cdot \nabla u=-\nabla p+\nabla \cdot\left(\mu\left(\nabla u+(\nabla u)^{T}\right)-\frac{2}{3} \mu(\nabla \cdot u) I\right)+F_{v}
$$

and the continuity equations (conservation of mass):

$$
\frac{\partial \rho}{\partial t}+\nabla \cdot(\rho u)=0
$$

where $\rho$ is the solution's density $\left(\mathrm{kg} / \mathrm{m}^{3}\right), \mu$ dynamic viscosity of the fluid $\left(\mathrm{Ns} / \mathrm{m}^{2}\right), u$ is the velocity vector $(\mathrm{m} / \mathrm{s}), I$ denote the identity matrix, $F_{v}$ is the volume force vector $\left(\mathrm{N} / \mathrm{m}^{3}\right), T$ is the absolute temperature $(\mathrm{K})$ and $p$ is pressure $(\mathrm{Pa})$. Another indication that the flow in this microreactor can be assumed as incompressible is that the Mach number (Ma) is much less than 0.3 for flow velocities $\leq 10 \mathrm{~m} / \mathrm{s}$.

The 2-D model of parallel rectangular microchannels with integrated inlet and outlet manifolds was generated for the four different potential geometries and the flow behavior was simulated for flow velocities between $0.01 \mathrm{~m} / \mathrm{s}$ and $100 \mathrm{~m} / \mathrm{s}$. A single phase laminar incompressible flow was simulated for cold flow (without reaction) at normal temperature and pressure. When combined with a no-slip boundary at the walls, a fully developed laminar flow condition at the inlet, and a pressure condition at the outlet, the Navier-Stokes equations describe the flow field in the channels.

The geometries were simulated, and the results were compared to determine the best configuration for the construction of a catalytic microreactor. Graphs showing flow rate and contour velocity plots were used to evaluate the results. Variations in fluid distribution were studied to evaluate and determine the best distribution from the viewpoint of flow uniformity in each of the parallel channels and was based on the values of the relative standard deviation across the channels. The simulation results indicated two flow regimes depending on the inlet velocity for the four geometries. For all geometries at low flow rates (below $10 \mathrm{~m} / \mathrm{s}$ ), the flow distribution appears to be completely determined by wall friction. In this regime all 4 geometries yielded similar results. For operation below this velocity the flow distribution appears to be independent of flow rate. At flow rates above a transitional velocity ( $60 \mathrm{~m} / \mathrm{s}$ for Type A2, A3, and A4 and $90 \mathrm{~m} / \mathrm{s}$ for type A1), inertial effects start to influence the flow distribution with a constant relative standard deviation. Geometries A2, A3, and A4 showed similar trends; for type A1 a different effect is observed, the relative standard deviation continues to 
increase until it appears to level off at a higher velocity. Type A2 gave the flow distribution with the lowest relative standard deviation and was extruded in a $3 \mathrm{D}$ for the construction of the microreactor.

\subsection{Reactor Fabrication}

The designed microreactor (Type A2) was fabricated in stainless steel (type $316 \mathrm{~L}$ ) plate of $8 \mathrm{~mm}$ thickness, by using a CNC (Computer Numerical Control) micro-milling machine. Two microchannel plates were fabricated by micro-milling 11 rectangular slots of $1 \mathrm{~mm} \times 1 \mathrm{~mm} \times 100 \mathrm{~mm}$ with a semi-circular inlet and outlet manifolds in SS 316L plates. This dimension will be reduced to $0.5 \mathrm{~mm} \times 0.5 \mathrm{~mm} \times 100 \mathrm{~mm}$ due to the catalyst coating on the microchannel wall. The CAD drawing of the microreactor (see Figure 9) was used to generate the NX-10 software code (see Figure 10). The generated code is shown having 12 drills, 11 slots/channels and 2 cavity/manifolds. The resulting microreactor produced from the generated code by the Bridgeport Interact 412X CNC milling machine (Bridgeport, UK) is shown in Figure 11. Three G-code were generated, one for the slots/channels, one for the cavity/manifold and the other was for the 12 drill.

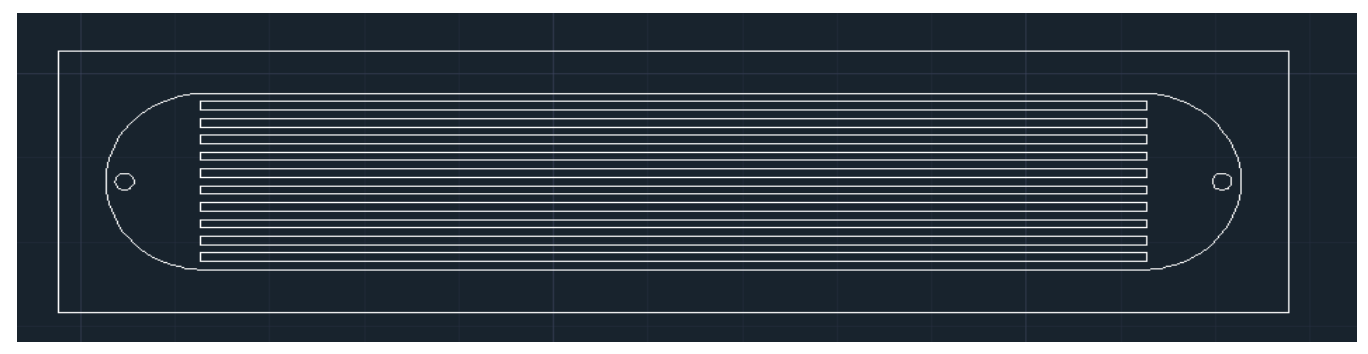

Figure 9. CAD drawing of the microreactor before loading to NX 10 software.

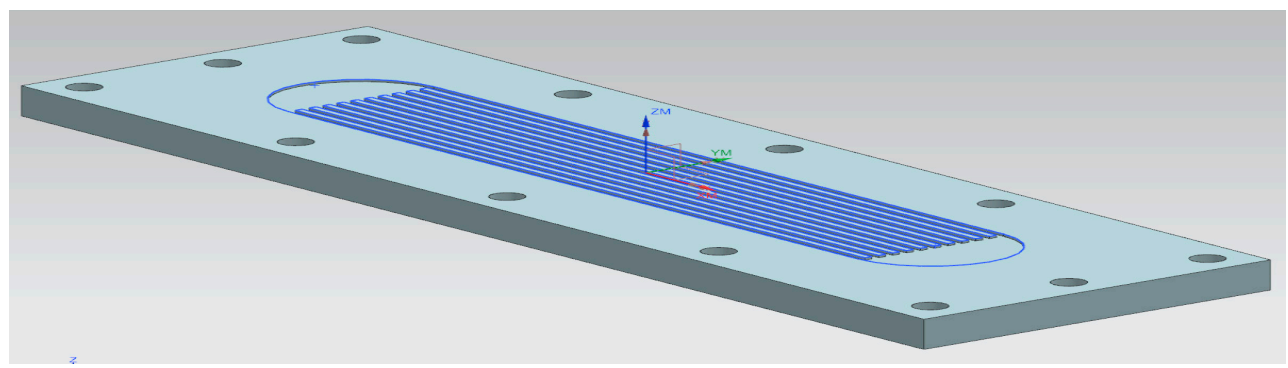

Figure 10. Generated microreactor code in NX 10 software.

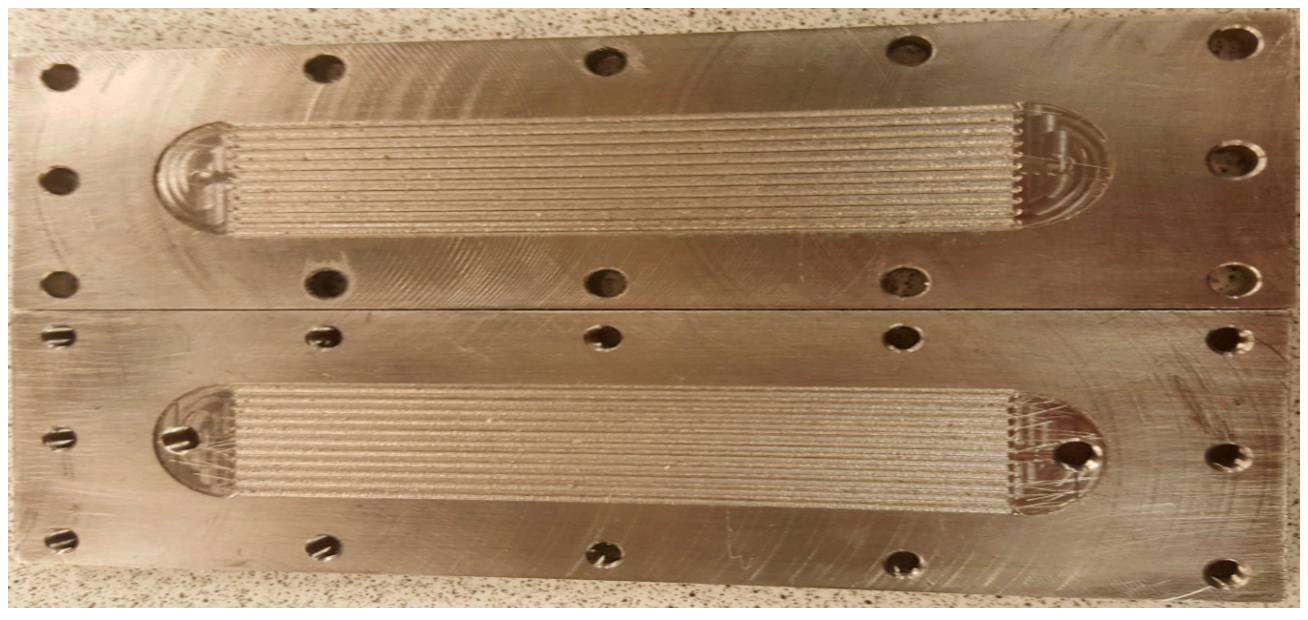

Figure 11. Photos of two fabricated microreactor plates having 11 rectangular parallel microchannels/ slots and inlet and outlet manifolds on stainless steel $315 \mathrm{~L}$. 
Stainless steel is selected based on its high corrosion resistance, strength and heat resistance. Type $316 \mathrm{~L}$ has very good resistance to corrosion because it is extremely low in carbon content. Its use has been broadened to handle many chemicals in the process industries. Machining characteristics of stainless steels are substantially different from other metals. In varying degree, most stainless steels, especially type $316 \mathrm{~L}$, are tough, gummy, and tend to seize and gall. It can withstand higher loads with greater unit stress. Stainless steel fasteners are easy to make unlike aluminum alloy. Aluminum is much softer than SS-316 L and easier to machine.

\subsection{Building the Microreactor System}

The images in Figure 12 show the sequence in which the system was built. Swagelok tubing (Swagelok, TX, USA), connectors and all accessories are connected on a $14 \times 10$-inch panel box. The aim is to be able to move the rig from one location to another. Swagelok tubing, two non-return valves, three pressure regulators, and a differential pressure transducer were first connected as seen in Figure 12A. Two mass flow controllers Bronkhorst (Brokhorst, UK) were then connected (Figure 12B). Two 3-way valves, fittings and three pressure transmitters were connected in sequence $\mathrm{C}$, then, sequence $\mathrm{D}$ followed, i.e., the electrical wiring up of the mass flow controllers, and then the differential pressure transmitter as seen in Figure 12E, sequence F for wiring of sensing instrument. Gems sensor and (OMEGA, U) temperature controller was done in sequence $\mathrm{G}$ and finally, as image $\mathrm{H}$ shows, the instrument panel meter was ready.

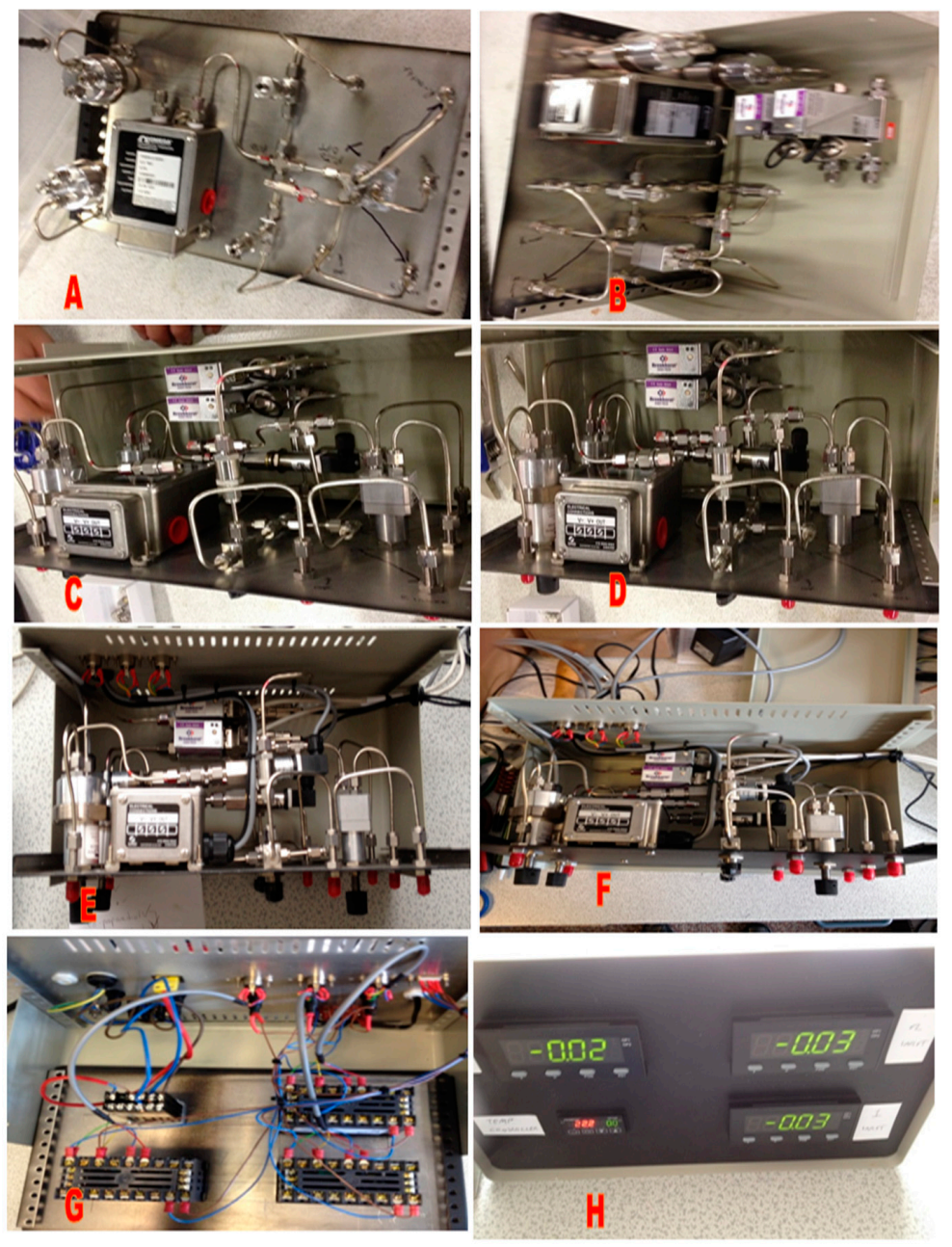

Figure 12. Step-by-step description of the building of the microreactor system. 


\subsection{Newly-Developed Au/SBA-15 Catalyst Preparation}

The catalyst was prepared by one-pot sol-gel synthesis of SBA-15 with MPTMS (3-mercaptopropyltrimethoxy-silane) before loading with $\mathrm{HAuCl}_{4}$ gold precursor.

One pot functionalization of SBA-15 with MPTMS was carried out as follows. First, $4 \mathrm{~g}$ of triblock copolymer (P123) was dissolved in $30 \mathrm{~mL}$ water with $120 \mathrm{~g}$ of $2 \mathrm{M} \mathrm{HCl}$ (final solution had $1.60 \mathrm{~mol} / \mathrm{L}$ $\mathrm{HCl}$ ) added and stirred at $35^{\circ} \mathrm{C}$ for $2 \mathrm{~h}$. Then, $8.5 \mathrm{~g}$ of silica precursor, tetraethyl orthosilicate (TEOS) in this case, was introduced drop wise with the solution stirred for $2 \mathrm{~h}$ at $35^{\circ} \mathrm{C}$. The addition of $0.6 \mathrm{~g}$ of MPTMS and stirring for another $18 \mathrm{~h}$ at $35^{\circ} \mathrm{C}$ followed. The suspension was filtered under vacuum, washed with water, then acetone and dried at $80^{\circ} \mathrm{C}$ overnight. P123 template removal from as-synthesized SBA-15-SH was done by ethanol soxhlet extraction for $48 \mathrm{~h}$. Recovered sample was dried at $60^{\circ} \mathrm{C}$ for $24 \mathrm{~h}$. $1.0 \mathrm{~g}$ of functionalized support was then suspended in $80 \mathrm{~mL}$ of distilled water and stirred for $30 \mathrm{~min}$ at $80^{\circ} \mathrm{C}$ before adding $0.08 \mathrm{~g}$ of $\mathrm{HAuCl}_{4} \cdot 3 \mathrm{H}_{2} \mathrm{O}$ dissolved in $10 \mathrm{~mL}$ water. After $20 \mathrm{~min}$, the solution was allowed to cool at room temperature for $20 \mathrm{~min}$ while stirring, then recovered by filtration, air dried for $18 \mathrm{~h}$ and then at $60^{\circ} \mathrm{C}$ for $24 \mathrm{~h}$ in an oven.

\subsection{Catalyst Characterzation}

Synthesized Au/SBA-15 catalyst was characterized before coating using the following techniques: Scanning Electron Microscopy/Energy Dispersive X-ray spectroscopy (SEM/EDX), Transmission Electron Microscopy (TEM), wide angle X-Ray Diffraction spectroscopy (XRD), and nitrogen physisorption measurements.

SEM was carried out with a Hitachi S-3400N scanning electron microscope (Hitachi, Japan) operated at an accelerating voltage in the $15-20 \mathrm{kV}$ range. EDX on the same instrument was used for elemental analysis and gold weight percent determination on the surface of SBA-15 support.

TEM images were obtained using a JEOL 2100F FEG transmission electron microscope (JEOL Ltd., Tokyo, Japan) operated at $200 \mathrm{kV}$. The catalyst sample was homogenously dispersed in pure acetone using ultrasonic bath and then deposited onto holey carbon grid. The acetone solvent was allowed to evaporate under vacuum before examination of the catalyst sample in TEM mode.

Wide angle X-ray powder diffraction patterns of Au/SBA-15 catalyst were collected in a Siemens D500 diffractometer (Siemens, Germany) with Bragg-Brentano geometry, using nickel-filtered Cu-K $\alpha$ radiation $(\lambda=0.15406 \mathrm{~nm})$, at tube voltage of $40 \mathrm{kV}$ and $20 \mathrm{~mA}$ current, with date collected over $2 \theta$ range from $10-90^{\circ}$ to determine the presence of gold on SBA-15, its crystalline structure and gold particle sizes which was done in conjunction with Scherrer equation.

Nitrogen adsorption-desorption isotherms were obtained in a Micrometrics Tristar II 3020 Surface Area and Porosity Analyser (Micromeritics Instruments Corporation, USA) at $77 \mathrm{~K}$. The catalyst sample was degassed at $350^{\circ} \mathrm{C}$, under vacuum, for two hours, before analysis. The surface area was calculated by BET method.

\subsection{Slurry Preparation, Catalyst Coating onto Microchannel and Characterization}

Although significant progress has been made in terms of the design and fabrication of micro-channel reactors, the introduction of the active catalyst in thin, firm and uniform layer which does not flake off from the channel walls remains a big research issue [71]. To analyze how well the support or catalysts binds to the metal surface, SEM is normally used to characterize the coatings which reveals if there are cracks or flaking of the catalyst from the microreactor channels.

Despite several publications on Au/SBA-15 catalysts and the unusually high activity of gold catalysts towards oxidation and hydrogenation reactions at lower temperatures [72-74], no publication was found for coating of any of Au/SBA-15 catalysts onto microreactors.

To develop the best coating technique three different coating methods where explored to coat the stainless steel machined microreactor, namely: 
1. Injecting catalyst, polyvinyl alcohol as binder with acetic acid slurry into the channels of the microreactor with a syringe (Technique 1).

2. Spraying catalyst, polyvinyl alcohol as binder with acetic acid slurry into the channels at room temperature using a manual fine airbrush with $0.3 \mathrm{~mm}$ nozzle (Technique 2).

3. Spraying catalyst-colloidal silica-methyl cellulose-water slurry with the same airbrush onto the micro-reactor plates heated up to $150^{\circ} \mathrm{C}$ (Technique 3).

For Technique 1, a small amount of Au/SBA-15 catalyst, i.e., $2.6 \mathrm{mg}$, was added to water, polyvinyl alcohol as binder with acetic acid in the weight ratio of 10:84:5:1. The mixture, while stirring, was heated at $65^{\circ} \mathrm{C}$ for $3 \mathrm{~h}$ and left to stir at room temperature for $1 \mathrm{~h}$ to achieve a homogenous solution. A syringe was manually used to fill each channel to the brim. The coated plates were dried at room temperature before heat treatment at $500{ }^{\circ} \mathrm{C}$ with ramping at $1 \%$ minute to remove the polyvinyl alcohol organic binder.

For Technique 2, the same catalyst slurry was used; however, a manual air brush with $0.3 \mathrm{~mm}$ nozzle and 2 bar air pressure was used to spray the catalyst slurry into all the channels of the microreactor. The coated plates were air dried before heat treatment at $500{ }^{\circ} \mathrm{C}$ to remove the polyvinyl alcohol organic binder.

Technique 3 used a mixture of $10 \mathrm{mg}$ catalyst, $7 \mathrm{~g}$ colloidal silica, $7 \mathrm{~g}$ methyl cellulose and $6 \mathrm{~g}$ of water. Homogeneity of the mixture for technique 3 was achieved within $30 \mathrm{~min}$ of stirring at room temperature as shown in Figure $13 \mathrm{~A}$. The reactor plate was heated at $150^{\circ} \mathrm{C}$ before spraying with the manual airbrush as shown in Figure 13B. The coated plates were air dried before heat treatment at $500{ }^{\circ} \mathrm{C}$ to remove methyl cellulose organic binder as shown in Figure 13C. Excess catalyst outside the channels in all cases were easily wiped off.

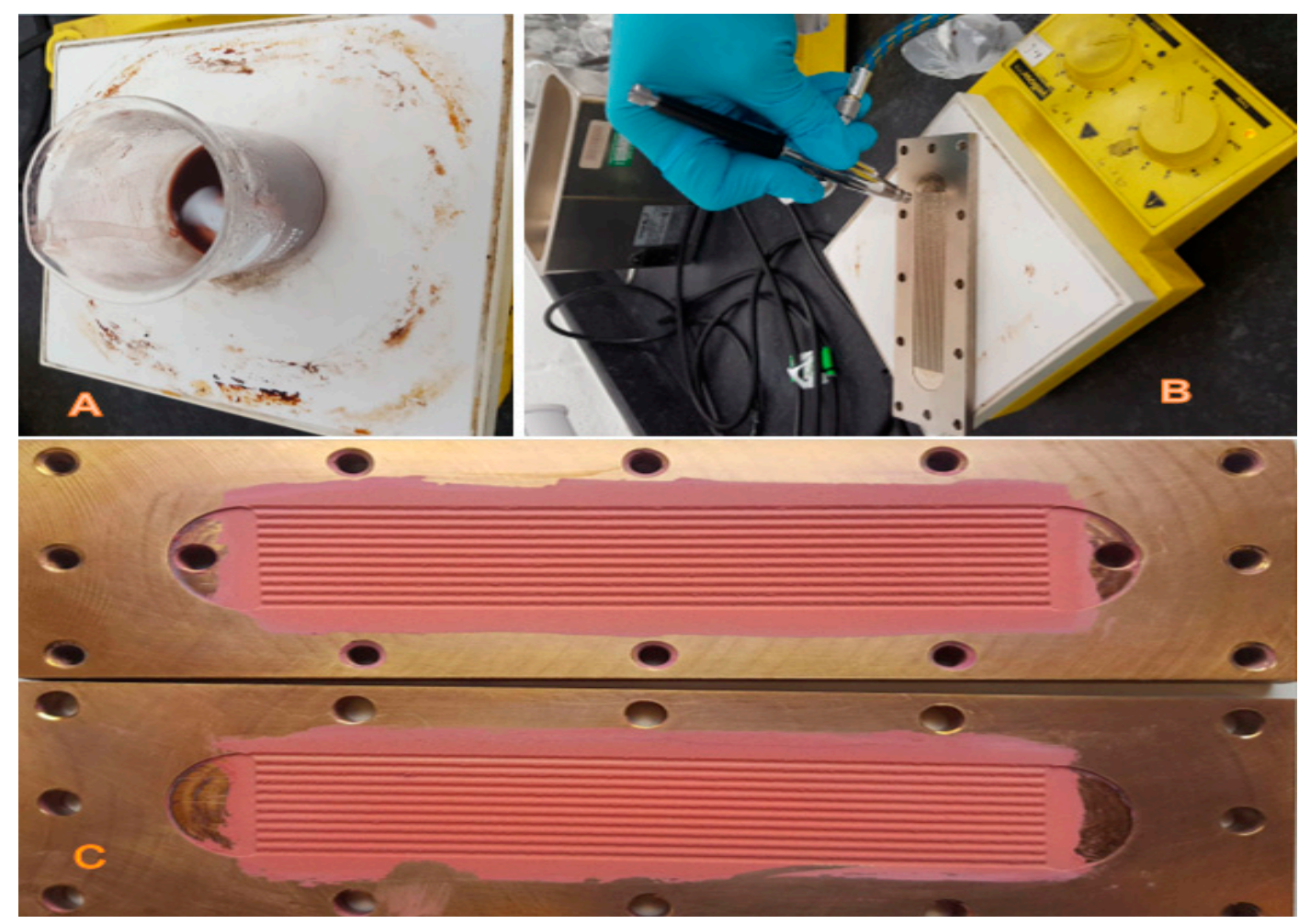

Figure 13. Catalyst preparation and spraying into the microchannels (Technique 3).

To improve the adherence of the catalyst layers onto the microchannels the microreactor was rinsed with acetone followed by deionized water and dried in an oven at $65^{\circ} \mathrm{C}$ to remove organic material from the surface prior to the catalyst deposition steps. 
The coatings in the channels of the micro-reactor were observed using GXCAM-5 microscope (Prior Scientific Instruments Ltd., Cambridge, UK) with a 5 MP resolution camera attached to capture images. Scanning Electron Microscopy Hitachi S-3400 N variable was used to view and capture the images of the coated microreactor channels with $500 \mu \mathrm{m}$ resolution.

\subsection{Experimental Setup and Procedure}

The microreactor system designed and built specifically for the purpose of this research was integrated into an experimental rig as shown in Figures 14 and 15.

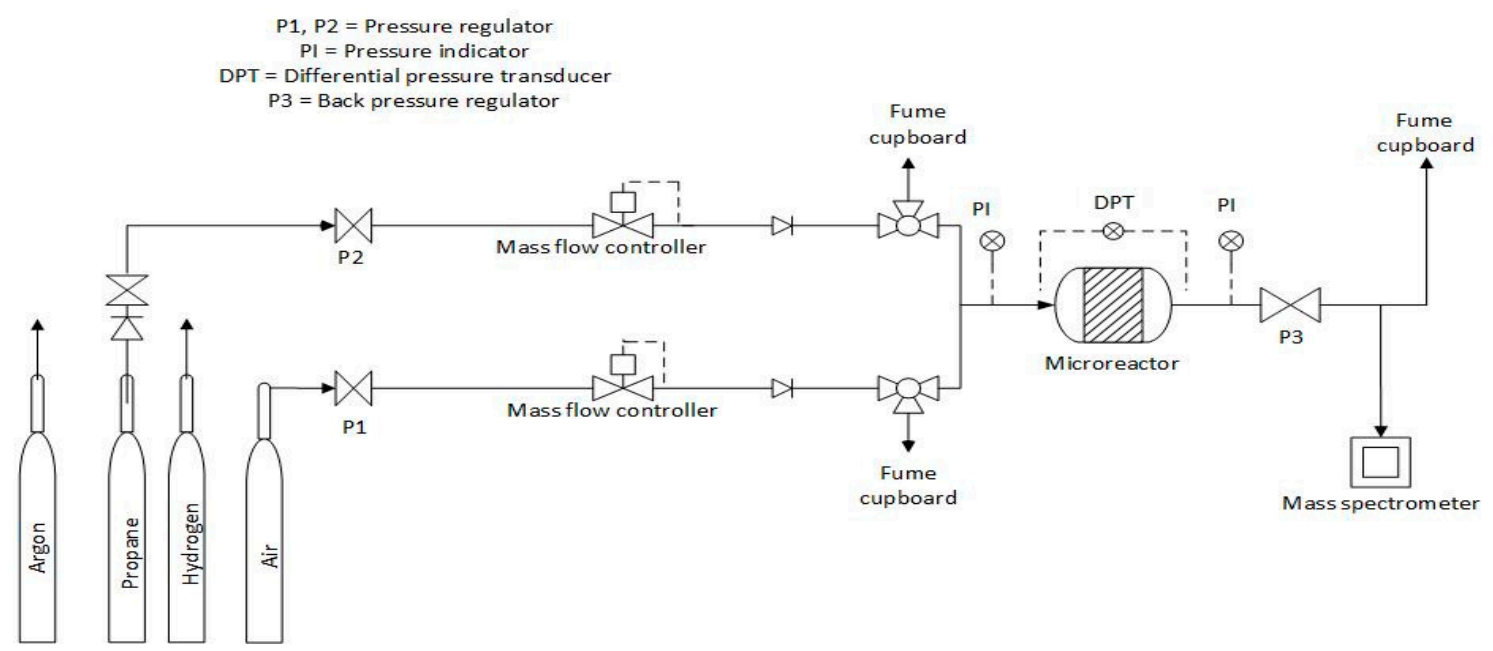

Figure 14. Scheme of the experimental setup for propane oxidation in the built microreactor.

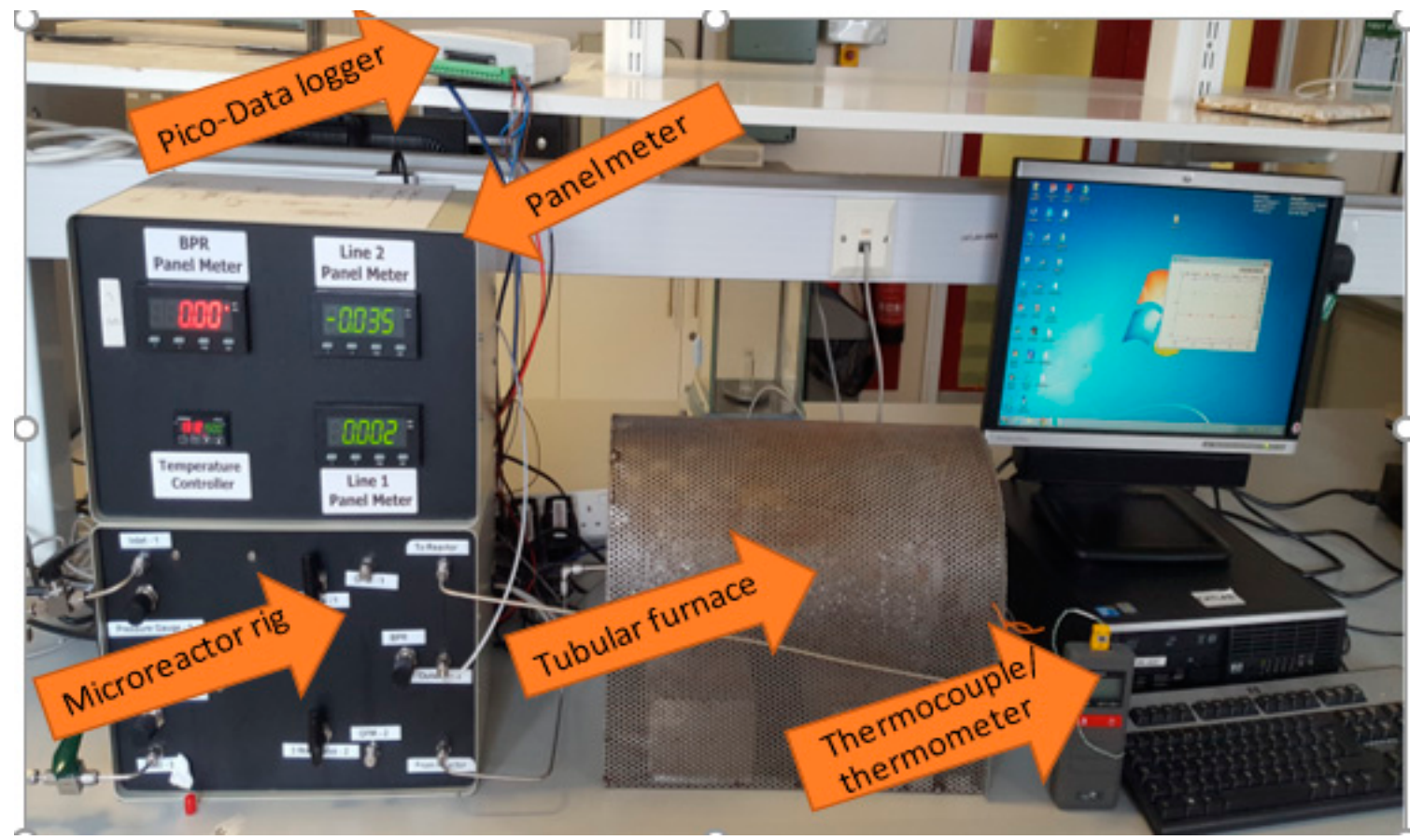

Figure 15. Photo of the microreactor system of the experimental setup.

The experimental set-up for the complete oxidation of propane (as model VOC) consists of the feeding system, the microreactor and the gas analyzer, which is a quadrupole mass spectrometer Hiden QIC-20. Twelve grooves were made across in the back of the plate, where a K-type thermocouple could be inserted in the middle groves to measure the temperature of the reaction plate. Stainless steel bolts 
were used to hold the different parts. The inlet and the outlet for the gases used $1 / 8^{\prime \prime}$ Swagelok fittings and $1 / 8^{\prime \prime}$ stainless steel tubing. The inlet and outlet holes were sealed with Viton O-rings to a heat able interface block that connects the external tubing to the microreactor. The pressure drop across the reactor was monitored using the differential pressure transducer.

A pressure drop leak test is performed prior switching on the furnace in order to make sure all the flow lines are leak proof. Once the desired temperature inside the furnace is stabilized, the reactants, a 1:5 propane to air mixture, at the desired flow rate are supplied upstream to the reactor using mass flow controllers operating in the range from $0-100 \mathrm{~mL} / \mathrm{min}$. The inlet and outlet gases to the mass flow controllers used $1 / 8$ " Swagelok fitting and stainless tubing. The error in the flow measurements is around $0.01 \%$ for each controller, and as such, the maximum error of about $0.02 \%$ in the gas mixture to the reactor could be expected.

High purity propane (99.9\%) and synthetic dry air (oxygen $20.995 \%-21.005 \%$ balance nitrogen) were used as the reactant gases. Assuming an oxygen concentration of $21 \%$ in air, the gas flow rates given in Table 3 were used.

Table 3. Flow rates and fuel to air molar ratio in the reactor.

\begin{tabular}{cccccc}
\hline \multicolumn{3}{c}{ Flow Rate $(\mathrm{mL} / \mathrm{min})$} & \multicolumn{2}{c}{$\begin{array}{c}\text { Fuel:Oxygen } \\
\text { Molar Ratio }\end{array}$} \\
\hline Propane & Air & Oxygen & Total flow rate $(\mathrm{mL} / \mathrm{min})$ & Propane & Oxygen \\
\hline 1 & 26.0 & 5.5 & 27 & 1 & 5.46 \\
\hline 1.2 & 32.0 & 6.7 & 33.2 & 1 & 5.6 \\
\hline 1.4 & 36.5 & 7.7 & 37.9 & 1 & 5.5 \\
\hline
\end{tabular}

Experiments were performed at a constant pressure of 1.36 bar. The reactor was heated stepwise to specific temperatures between 150 and $300{ }^{\circ} \mathrm{C}$. The microreactor effluent is piped directly to the gas analyzer. The line connecting the microreactor and the gas analyzer is insulated to avoid condensing water formed in the product line. Partial pressure of propane and reaction products in the effluent flow was monitored continuously at each temperature for at least $1 \mathrm{~h}$ until equilibrium was established. Mass spectrometer can be used to perform both qualitative and quantitative measurements. A MID (multiple ion detector) was used to directly monitor the following ions: propane $(\mathrm{m} / \mathrm{z}=29)$, $\mathrm{CO}_{2}(\mathrm{~m} / \mathrm{z}=44)$, water $(\mathrm{m} / \mathrm{z}=18)$, and oxygen $(\mathrm{m} / \mathrm{z}=32)$, as the sample was heated up to $300{ }^{\circ} \mathrm{C}$. The catalytic activity was measured at $150{ }^{\circ} \mathrm{C}, 200{ }^{\circ} \mathrm{C}$ and then the temperature was increased in $25^{\circ} \mathrm{C}$ increments to $300^{\circ} \mathrm{C}$. The wall temperature is taken as the reactor temperature, because the temperature difference between the upper cover wall and the actual reacting species is considered negligible.

The propane complete oxidation follows the reaction shown in Equation (5).

$$
\mathrm{C}_{3} \mathrm{H}_{8}+5 \mathrm{O}_{2}=>3 \mathrm{CO}_{2}+4 \mathrm{H}_{2} \mathrm{O}
$$

The catalyst coated microreactor was initially treated with $5 \% \mathrm{H}_{2}$ in argon stream $30 \mathrm{~mL} / \mathrm{min}$ at $300{ }^{\circ} \mathrm{C}$ for $2 \mathrm{~h}$ and then flushed with a pure argon flow for $30 \mathrm{~min}$. In order to avoid any re-oxidation of the catalyst prior to the reaction, $\mathrm{C}_{3} \mathrm{H}_{8}$ flow was fed immediately after and allowed to stabilize before adding the air flow to the feed. Prior to the catalytic study, thermal oxidation experiments were performed using the non-coated reactor. This allowed measurements to be made that distinguished between catalytic oxidation effects and thermal conversion effects. There was no measurable thermal oxidation reaction at the temperatures observed. Propane conversion was calculated using Equation (4).

In order to get robust gas composition/conversion data (accurate and reliable) the gas analysis was repeated for two consecutive samples/experiments.

$$
X_{\mathrm{C} 3 \mathrm{H} 8}=\frac{\gamma_{i_{\mathrm{C} 3 \mathrm{H} 8}}-\gamma_{f_{\mathrm{C} 3 \mathrm{H} 8}}}{\gamma_{i_{\mathrm{C} 3 \mathrm{H} 8}}} \times 100
$$


where $X_{\mathrm{C} 3 \mathrm{H} 8}$ is the fractional conversion of propane, $\gamma_{i_{\mathrm{C} 3 \mathrm{H} 8}}$ is the initial partial pressure of propane in torr (experimental run without catalyst), and $\gamma_{f_{C 3 H 8}}$ is the final partial pressure of propane in torr.

\subsection{Heating the Reactor}

A tubular furnace has been designed and built consisting of a tubular stainless steel pipe $(35 \mathrm{~cm}$ length and $10 \mathrm{~cm}$ diameter) coiled with a fiber glass heating tape (Omega Engineering Inc. Manchester, UK, FGH102-100, $1040 \mathrm{~W}, 240 \mathrm{~V}$ ) and a ceramic jacket (VITCAS ceramic fiber blanket $25 \mathrm{~mm}$ thick) (which was used to prevent the heat loss). The ceramic fiber blanket is wrapped with a heat resistant aluminum foil tape, $25 \mathrm{~mm} \times 45 \mathrm{~m}$ for excellent insulation. The microreactor is introduced at the center of the tubular furnace. Its temperature is monitored by a K-type thermocouple with $1 \mathrm{~ms}$ time response (according to the manufacturer), inserted at the wall (see Figure 16). The high temperature heating tape is controlled using an auto tuning PID temperature controller (Omega Engineering, Inc., Manchester, UK, CN7500 series). The temperature controller is mounted on the front of the instrument cabinet/panel meter for the purpose of regulating the energy that is used to heat the furnace.
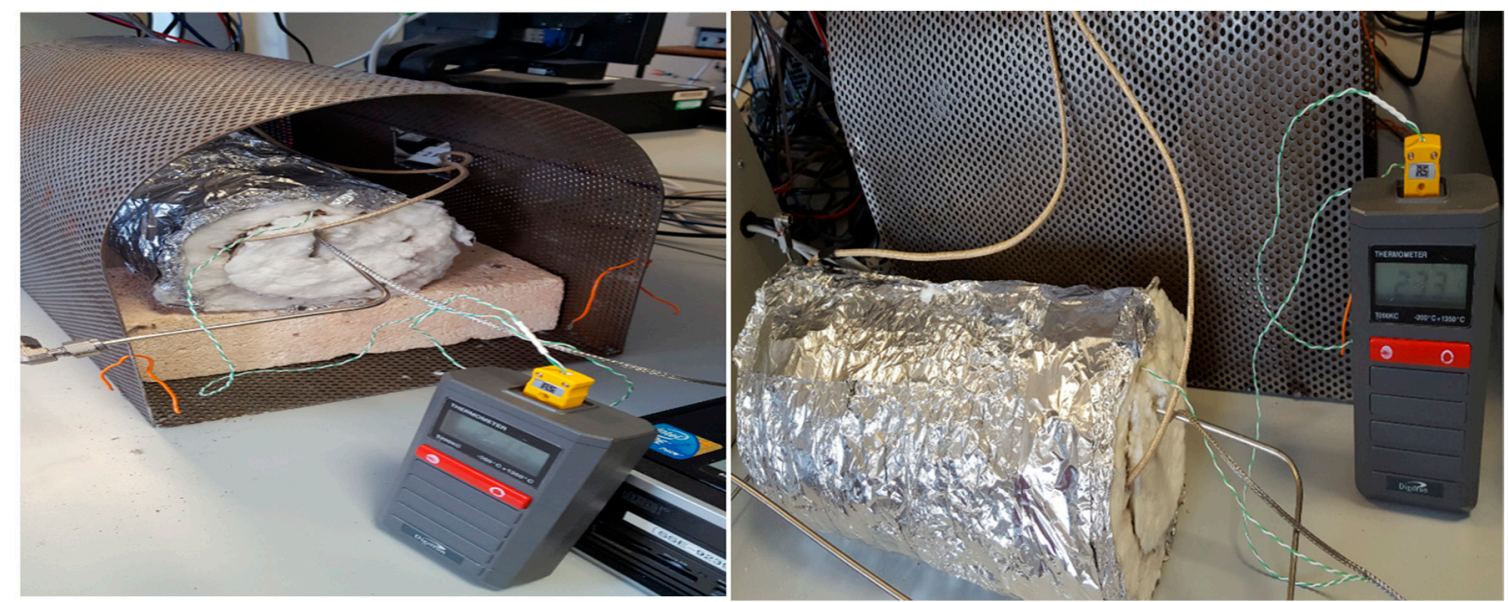

Figure 16. Tubular furnace sealed with ceramic fiber blanket with the microreactor inserted at the center of the furnace.

It is necessary to achieve a steady temperature inside the furnace before allowing gases to flow to the analyzer. To do this, the temperature controller plug is switched on to power the heating tape.

The heating tape and an auto tuning PID controller with a thermocouple sensor maintained the furnace temperature to within $1^{\circ} \mathrm{C}$ of the set point.

\section{Conclusions}

The experimental operation of the microreactor with the propane/air mixture showed that propane conversions increased with temperature but decreased as the flow rates increased at the same temperatures. It did appear that for the microreactor constructed and the flows and temperatures set the combustion of propane was possible with measurable conversions and reasonable reactor stability. The performance of an active and stable Au/SBA-15 catalyst appeared to be central to the satisfactory operation of the reactor.

This work has demonstrated that it is possible to design and model/simulate a microreactor by using CFD calculations and then to build the physical reactor based on the design results and to exploit it to achieve the predicted results.

Based on literature data [75,76] and our assessment of the catalytic activity, we assume that the total oxidation of propane is well-described by a Mars-van Krevelen mechanism. 
Author Contributions: Conceptualization, S.O. and M.O. methodology, S.O., M.O., E.I., P.R. and A.A.; investigation, S.O., M.O., T.S., E.I. and P.R.: writing-original draft preparation, S.O., M.O. and S.H.; writing-review and editing, M.O. and S.O.; supervision, M.O., S.H. and A.A. All authors have read and agreed to the published version of the manuscript.

Funding: This research received no external funding.

Conflicts of Interest: The authors declare no conflict of interest.

\section{References}

1. Grassian, V.H. Environmental Catalysis. CRC Press: Boca Raton, FL, USA, 2005.

2. Maroni, M.; Seifert, B.; Lindvall, T. (Eds.) Indoor Air Quality: A Comprehensive Reference Book; Elsevier: Amsterdam, The Netherlands, 1995; Volume 3.

3. VOC Solvents Directive Environment European Commission 1999/13/EC. Available online: http://ec.europa. eu/environment/archives/air/stationary/solvents/faq_en.htm (accessed on 1 October 2019).

4. Ryerson, T.; Trainer, M.; Holloway, J.; Parrish, D.; Huey, L.; Sueper, D.; Frost, G.; Donnelly, S.; Schauffler, S.; Atlas, E. Observations of ozone formation in power plant plumes and implications for ozone control strategies. Science 2001, 292, 719-723. [CrossRef] [PubMed]

5. Atkinson, R.; Arey, J. Atmospheric degradation of volatile organic compounds. Chem. Rev. 2003, 103, 4605-4638. [CrossRef] [PubMed]

6. World Health Organization. Indoor Air Quality: Organic Pollutants; The WHO European Centre for Environment and Health, Bonn Office: Copenhagen, Denmark, 1989.

7. Field, R.; Goldstone, M.; Lester, J.; Perry, R. The sources and behaviour of tropospheric anthropogenic volatile hydrocarbons. Atmos. Environ. Part A Gen. Top. 1992, 26, 2983-2996. [CrossRef]

8. Wang, S.; Ang, H.; Tadé, M.O. Volatile organic compounds in indoor environment and photocatalytic oxidation: State of the art. Environ. Int. 2007, 33, 694-705. [CrossRef] [PubMed]

9. Bertoni, G.; Ciuchini, C.; Pasini, A.; Tappa, R. Monitoring of ambient BTX at Monterotondo (Rome) and indoor-outdoor evaluation in school and domestic sites. J. Environ. Monit. 2002, 4, 903-909. [CrossRef]

10. Lyon, F. IARC Monographs on the Evaluation of Carcinogenic Risks to Humans; WHO International Agency for Research on Cancer: Lyon, France, 2014.

11. Lawryk, N.J.; Weisel, C.P. Concentrations of Volatile Organic Compounds in the Passenger Compartments of Automobiles. Environ. Sci. Technol. 1996, 30, 810-816. [CrossRef]

12. You, K.-W.; Ge, Y.-S.; Hu, B.; Ning, Z.-W.; Zhao, S.-T.; Zhang, Y.-N.; Xie, P. Measurement of in-vehicle volatile organic compounds under static conditions. J. Environ. Sci. 2007, 19, 1208-1213. [CrossRef]

13. Leung, P.-L.; Harrison, R.M. Roadside and in-vehicle concentrations of monoaromatic hydrocarbons. Atmos. Environ. 1999, 33, 191-204. [CrossRef]

14. Finlayson-Pitts, B.J.; Pitts, J.N. Tropospheric Air Pollution: Ozone, Airborne Toxics, Polycyclic Aromatic Hydrocarbons, and Particles. Science 1997, 276, 1045-1051. [CrossRef]

15. Beeson, W.L.; Abbey, D.E.; Knutsen, S.F. Long-Term Concentrations of Ambient Air Pollutants and Incident Lung Cancer in California Adults: Results from the AHSMOG Study. Environ. Health Perspect. 1998, 106, 813. [CrossRef]

16. Woodruff, T.J.; Axelrad, D.A.; Caldwell, J.; Morello-Frosch, R.; Rosenbaum, A. Public health implications of 1990 air toxics concentrations across the United States. Environ. Health Perspect. 1998, 106, 245-251. [CrossRef] [PubMed]

17. Huff, J.; Melnick, R.; Solleveld, H.; Haseman, J.; Powers, M.; Miller, R. Multiple organ carcinogenicity of 1, 3-butadiene in B6C3F1 mice after 60 weeks of inhalation exposure. Science 1985, 227, 548-549. [CrossRef] [PubMed]

18. Filser, J.G.; Bolt, H.M. Inhalation pharmacokinetics based on gas uptake studies. Arch. Toxicol. 1984, 55, 219-223. [CrossRef] [PubMed]

19. Bond, J.A.; Csanady, G.A.; Gargas, M.L.; Guengerich, F.P.; Leavens, T.; Medinsky, M.A.; Recio, L. 1, 3-Butadiene: Linking metabolism, dosimetry, and mutation induction. Environ. Health Perspect. 1994, 102, 87-94. [CrossRef] 
20. Wang, X.; Sheng, G.-Y.; Fu, J.-M.; Chan, C.-Y.; Lee, S.-C.; Chan, L.Y.; Wang, Z.-S. Urban roadside aromatic hydrocarbons in three cities of the Pearl River Delta, People's Republic of China. Atmos. Environ. 2002, 36, 5141-5148. [CrossRef]

21. Hertel, O.; Jensen, S.S.; Andersen, H.V.; Palmgren, F.; Wåhlin, P.; Skov, H.; Nielsen, I.V.; Sørensen, M.; Loft, S.; Raaschou-Nielsen, O. Human exposure to traffic pollution. Experience from Danish studies. Pure Appl. Chem. 2001, 73, 137-145. [CrossRef]

22. Stemmler, K.; Bugmann, S.; Buchmann, B.; Reimann, S.; Staehelin, J. Large decrease of VOC emissions of Switzerland's car fleet during the past decade: Results from a highway tunnel study. Atmos. Environ. 2005, 39, 1009-1018. [CrossRef]

23. Hansen, A.B.; Palmgren, F. VOC air pollutants in Copenhagen. Sci. Total Environ. 1996, 189, $451-457$. [CrossRef]

24. Buczynska, A.J.; Krata, A.; Stranger, M.; Godoi, A.F.L.; Kontozova-Deutsch, V.; Bencs, L.; Naveau, I.; Roekens, E.; Van Grieken, R. Atmospheric BTEX-concentrations in an area with intensive street traffic. Atmos. Environ. 2009, 43, 311-318. [CrossRef]

25. Kim, S.; Kim, J.-A.; An, J.-Y.; Kim, H.-J.; Moon, S.-J. Development of a test method using a VOC analyzer to measure VOC emission from adhesives for building materials. J. Adhes. Sci. Technol. 2006, 20, 1783-1799. [CrossRef]

26. Kim, Y.M.; Harrad, S.; Harrison, R.M. Concentrations and sources of VOCs in urban domestic and public microenvironments. Environ. Sci. Technol. 2001, 35, 997-1004. [CrossRef] [PubMed]

27. Guo, H.; Lee, S.-C.; Li, W.; Cao, J. Source characterization of BTEX in indoor microenvironments in Hong Kong. Atmos. Environ. 2003, 37, 73-82. [CrossRef]

28. Guo, H.; Lee, S.-C.; Chan, L.Y.; Li, W.M. Risk assessment of exposure to volatile organic compounds in different indoor environments. Environ. Res. 2004, 94, 57-66. [CrossRef]

29. The Paints Directive 2004/42/EC; European Parliament and Council Legislation: Brussels, Belgium, 2004.

30. Wolkoff, P. Trends in Europe to reduce the indoor air pollution of VOCs. Indoor Air 2003, 13, 5-11. [CrossRef] [PubMed]

31. Luo, M.-F.; Yuan, X.-X.; Zheng, X.-M. Catalyst characterization and activity of Ag-Mn, Ag-Co and Ag-Ce composite oxides for oxidation of volatile organic compounds. Appl. Catal. A Gen. 1998, 175, 121-129. [CrossRef]

32. Lu, C.-Y.; Wey, M.-Y. Simultaneous removal of VOC and NO by activated carbon impregnated with transition metal catalysts in combustion flue gas. Fuel Process. Technol. 2007, 88, 557-567. [CrossRef]

33. Moretti, E.C. Reduce VOC and HAP emissions. Chem. Eng. Prog. 2002, 98, 30-40.

34. Spivey, J.J. Complete catalytic oxidation of volatile organics. Ind. Eng. Chem. Res. 1987, 26, 2165-2180. [CrossRef]

35. Wang, C.-H.; Lin, S.-S.; Chen, C.-L.; Weng, H.-S. Performance of the supported copper oxide catalysts for the catalytic incineration of aromatic hydrocarbons. Chemosphere 2006, 64, 503-509. [CrossRef]

36. Belapurkar, A.; Kamble, V.; Dey, G. Photo-oxidation of ethylene in gas phase and methanol and formic acid in liquid phase on synthesized $\mathrm{TiO} 2$ and $\mathrm{Au} / \mathrm{TiO} 2$ catalysts. Mater. Chem. Phys. 2010, 123, 801-805. [CrossRef]

37. Zaitan, H.; Bianchi, D.; Achak, O.; Chafik, T. A comparative study of the adsorption and desorption of o-xylene onto bentonite clay and alumina. J. Hazard. Mater. 2008, 153, 852-859. [CrossRef] [PubMed]

38. Attaway, H.; Gooding, C.H.; Schmidt, M.G. Biodegradation of BTEX vapors in a silicone membrane bioreactor system. J. Ind. Microbiol. Biotechnol. 2001, 26, 316-325. [CrossRef] [PubMed]

39. Zuo, S.; Zhou, R. Al-pillared clays supported rare earths and palladium catalysts for deep oxidation of low concentration of benzene. Appl. Surf. Sci. 2006, 253, 2508-2514. [CrossRef]

40. Taylor, M.; Ndifor, E.N.; García, T.; Solsona, B.; Carley, A.F.; Taylor, S.H. Deep oxidation of propane using palladium-titania catalysts modified by niobium. Appl. Catal. A Gen. 2008, 350, 63-70. [CrossRef]

41. Solsona, B.; Davies, T.E.; Garcia, T.; Vázquez, I.; Dejoz, A.; Taylor, S.H. Total oxidation of propane using nanocrystalline cobalt oxide and supported cobalt oxide catalysts. Appl. Catal. B Environ. 2008, 84, 176-184. [CrossRef]

42. Solsona, B.; García, A.M.D.; Aylón, E.; Dejoz, A.M.; Vázquez, I.; Agouram, S.; Davies, T.E.; Taylor, S.H. Promoting the activity and selectivity of high surface area Ni-Ce-O mixed oxides by gold deposition for VOC catalytic combustion. Chem. Eng. J. 2011, 175, 271-278. [CrossRef] 
43. Morales, M.; Barbero, B.; Cadús, L.E. Total oxidation of ethanol and propane over Mn-Cu mixed oxide catalysts. Appl. Catal. B Environ. 2006, 67, 229-236. [CrossRef]

44. Jo, W.-K.; Park, J.-H.; Chun, H.-D. Photocatalytic destruction of VOCs for in-vehicle air cleaning. J. Photochem. Photobiol. A Chem. 2002, 148, 109-119. [CrossRef]

45. Mo, J.; Zhang, Y.; Xu, Q.; Lamson, J.J.; Zhao, R. Photocatalytic purification of volatile organic compounds in indoor air: A literature review. Atmos. Environ. 2009, 43, 2229-2246. [CrossRef]

46. Haruta, M.; Kobayashi, T.; Sano, H.; Yamada, N. Novel gold catalysts for the oxidation of carbon monoxide at a temperature far below $0{ }^{\circ} \mathrm{C}$. Chem. Lett. 1987, 405-408. [CrossRef]

47. Gluhoi, A.C.; Nieuwenhuys, B.E. Catalytic oxidation of saturated hydrocarbons on multicomponent $\mathrm{Au} / \mathrm{Al} 2 \mathrm{O} 3$ catalysts: Effect of various promoters. Catal. Today 2007, 119, 305-310. [CrossRef]

48. Ehrfeld, W.; Hessel, V.; Lowe, H. Extending the Knowledge Base in Microfibrication towards Chemical Engineering and Fluid Dynamic Simulation. In Proceedings of the Fourth International Conference on Microreaction Technology (IMRET4), Atlanta, GA, USA, 5-9 March 2003.

49. Ehrfeld, W.; Hessel, V.; Mokbius, H.; Russow, K. Potential and Realization of Microreactors; Ehrfeld, W., Ed.; Verlag Chemie, DECHEMA: Weinheim, Germany, 1996; pp. 1-28.

50. Jensen, K.F. Microreaction engineering-Is small better? Chem. Eng. Sci. 2001, 56, 293-303. [CrossRef]

51. Hessel, V.; Knobloch, C.; Löwe, H. Review on Patents in Microreactor and Micro Process Engineering. Recent Patents Chem. Eng. 2008, 1, 1-16. [CrossRef]

52. Loebbecke, S.; Antes, J.; Ferstl, W.; Boskovic, D.; Tuercke, T.; Schwarzer, M.; Krause, H. Microreactors for Processing of Hazardous and Explosible Reactions; IChemE SYMPOSIUM Series No.153; IChemE: Pfinztal, Germany, 2007; p. 153.

53. Zaborenko, N.; Murphy, E.R.; Kralj, J.G.; Jensen, K.F. Synthesis and Kinetics of Highly Energetic Intermediates by Micromixers: Direct Multistep Synthesis of Sodium Nitrotetrazolate. Ind. Eng. Chem. Res. 2010, 49, 4132-4139. [CrossRef]

54. Hessel, V.; Hardt, S.; Lowe, H.; Muller, A.; Kolb, G. Chemical Micro Process Engineering; Weiley-VCH: Weinheim, Germany, 2005.

55. Arana, L.R.; Schaevitz, S.B.; Franz, A.J.; Schmidt, M.A.; Jensen, K.F. A microrefabricated suspended-tube chemical reactor for thermally efficient fuel processing. J. Microelectromech Syst. 2003, 12, 600-612. [CrossRef]

56. Blackwell, B.S. Design, Fabrication, and Characterization of a Micro Fuel Processor; Massachusetts Institute of Technology, Department of Chemical Engineering: Cambridge, MA, USA, 2007; p. 174.

57. Bermel, P.; Ghebrebrhan, M.; Chan, W.; Yeng, Y.X.; Araghchini, M.; Hamam, R.; Marton, C.H.; Jensen, K.F.; Soljačić, M.; Joannopoulos, J.D.; et al. Design and global optimization of high-efficiency thermophotovoltaic systems. Opt. Express 2010, 18, A314-A334. [CrossRef]

58. El-Ali, J.; Sorger, P.K.; Jensen, K.F. Cells on chips. Nature 2006, 442, 403-411. [CrossRef]

59. Kerby, M.; Legge, R.S.; Tripathi, A. Measurements of Kinetic Parameters in a Microfluidic Reactor. Anal. Chem. 2006, 78, 8273-8280. [CrossRef]

60. Ferstl, W.; Klähn, T.; Schweikert, W.; Billeb, G.; Schwarzer, M.; Loebbecke, S. Inline Analysis in Microreaction Technology: A Suitable Tool for Process Screening and Optimization. Chem. Eng. Technol. 2007, 30, 370-378. [CrossRef]

61. Leung, S.-A.; Winkle, R.F.; Wootton, R.C.R.; Demello, A.J. A method for rapid reaction optimisation in continuous-flow microfluidic reactors using online Raman spectroscopic detection. Analyst 2005, 130, 46-51. [CrossRef]

62. Odiba, S.S.; Olea, S.M.; Hodgson, A.; Adgar, P.A. Russell, Computational fluid dynamics in microreactors analysis and design: Application to catalytic oxidation of volatile organic compounds. J. Chem. Eng. Process Technol. 2016, 7, 1-11.

63. Delsman, E.R.; Pierik, A.; De Croon, M.J.; Kramer, G.J.; Schouten, J.C. Microchannel Plate Geometry Optimization for Even Flow Distribution at High Flow Rates. Chem. Eng. Res. Des. 2004, 82, 267-273. [CrossRef]

64. Bogojevic, D.; Sefiane, K.; Walton, A.J.; Christy, J.R.; Cummins, G.; Lin, H. Investigation of Flow Distribution in Microchannels Heat Sinks for Two phase Flows. Heat Transfer. Eng. 2009, 13, 1049-1057. [CrossRef]

65. Tonomura, O.; Kano, M.; Hesebe, S. Shape Optimization of Microchannels Using CFD and Adjoint Method. In Proceedings of the 20th European Symposium on Computer Aided Process Engineering; Pierucci, S., Buzzi, F.G., Eds.; Elsevier: Amsterdam, The Netherlands, 2010; Volume 28, pp. 37-42. 
66. Ni, Z.; Seebauer, E.G.; Masel, R.I. Effects of Microreactor Geometry on Performance: Differences between Posted Reactors and Channel Reactors. Ind. Eng. Chem. Res. 2005, 44, 4267-4271. [CrossRef]

67. Pan, M.; Tang, Y.; Yu, H.; Chen, H. Modeling of velocity distribution among microchannels with triangle manifolds. AIChE J. 2009, 55, 1969-1982. [CrossRef]

68. Pan, M.; Zeng, D.; Tang, Y.; Chen, N. CFD-based Study of Velocity Distribution among Multiple Parallel Microchannels. J. Comput. 2009, 4, 1133-1138. [CrossRef]

69. Commenge, J.-M.; Falk, L.; Corriou, J.-P.; Matlosz, M. Optimal design for flow uniformity in microchannel reactors. AIChE J. 2002, 48, 345-358. [CrossRef]

70. Anderson, J.D. Computational Fluid Dynamics; McGraw-Hill, Inc.: New York, NY, USA, 1995.

71. Chen, H.; Bednarova, L.; Besser, R.; Lee, W.Y. Surface-selective infiltration of thin-film catalyst into microchannel reactors. Appl. Catal. A Gen. 2005, 286, 186-195. [CrossRef]

72. Grasselli, R.; Oyama, S.; Gaffney, A.; Lyons, J. Gold as a low-temperature oxidation catalyst: Factors controlling activity and selectivity. In Proceedings of the 3rd World Congress on Oxidation Catalysis, San Diego, CA, USA, 21-26 September 1997; p. 123.

73. Haruta, M. Size- and support-dependency in the catalysis of gold. Catal. Today 1997, 36, 153-166. [CrossRef]

74. Hutchings, G.J. Catalysis: A golden future. Gold Bull. 1996, 29, 123-130. [CrossRef]

75. Lin, J.N.; Wan, B.Z. Reaction Kinetics of Propane Catalytic Combustion on $\mathrm{Cr} / \gamma-\mathrm{Al}_{2} \mathrm{O}_{3}, \mathrm{Co} / \mathrm{Cr} / \gamma-\mathrm{Al}_{2} \mathrm{O}_{3}$, and $\mathrm{Au} / \mathrm{Cr} / \gamma-\mathrm{Al}_{2} \mathrm{O}_{3}$. J. Chin. Inst. Chem. Eng. 2004, 35, 149-159.

76. Olea, M.; Sack, I.; Balcaen, V.; Marin, G.B.; Poelman, H.; Eufinger, K.; Poelman, D.; De Gryse, R.; Paul, J.S.; Sels, B.F.; et al. DC magnetron sputter deposited vanadia catalysts for oxidation processes. Appl. Catal. A Gen. 2007, 318, 37-44. [CrossRef]

(C) 2020 by the authors. Licensee MDPI, Basel, Switzerland. This article is an open access article distributed under the terms and conditions of the Creative Commons Attribution (CC BY) license (http://creativecommons.org/licenses/by/4.0/). 